\title{
ASPECTOS MACHISTAS NA ORGANIZAÇÃO DO CONHECIMENTO: A REPRESENTAÇÃO DA MULHER EM INSTRUMENTOS DOCUMENTÁRIOS
}

\author{
ASPECTOS MACHISTAS EN LA ORGANIZACIÓN DEL \\ CONOCIMIENTO: LA REPRESENTACIÓN DE LA MUJER \\ EN INSTRUMENTOS DOCUMENTALES
}

\author{
Brisa Pozzi de Sousa* \\ Vinicius de Souza Tolentino**
}

\begin{abstract}
RESUMO:
Introdução: Abordar o tema mulher justifica-se pela forma como esse assunto tem desencadeado transformações que precisam ser compreendidas pela Organização do Conhecimento (OC), envolvendo tanto o aspecto temático quanto descritivo. A investigação não pode estar desvinculada do contexto social, pois os limites e as definições acerca do tema não são fixos e indefiníveis e necessita de discussões. Objetivos: Consiste na análise de descritores (nos tesauros) e de regras (no AACR2r) que suscitem a indicação de representações machistas, pois se torna imprescindível que profissionais tenham olhar crítico sobre o uso dos referidos instrumentos. Metodologia: Analisa a representação com foco na mulher, em três diferentes instrumentos: o Tesauro para Estudos de Gênero e Sobre Mulheres (TEG), o Tesauro Jurídico do Superior Tribunal de Justiça (TJ STJ) e o Anglo American Cataloguing Rules, $2^{\mathrm{a}}$ edição (AACR2r). Para averiguar o que se propõe, a sistematização do referencial teórico consiste no delineamento sobre OC, a mulher e os instrumentos. Resultados: As análises demonstram posturas machistas nos recortes investigados, permitindo constatar a necessidade de revisão dos três instrumentos, demandando atualização dos conceitos para que os descritores e as regras mantenham-se coerentes com a (re)configuração social livre de preconceito. Conclusões: Se o processo de representação for imbuído de preconceitos, tanto pelo fato do instrumento não ser atualizado ou por desconhecimento em relação ao domínio gênero, o impacto surtirá efeito negativo no público usuário.
\end{abstract}

Palavras-chave: Organização do Conhecimento. Gênero. Mulher. Tesauros. Regras de catalogação.

\footnotetext{
* Mestre pelo Programa de Pós-Graduação em Ciência da Informação da Unesp campus de Marília e Doutoranda no Programa de Pós-Graduação em Ciência da Informação da UFMG. Atua como docente nos cursos de Biblioteconomia da UNIRIO. Email: brisapozzi@gmail.com.

** Mestre e Doutorando no Programa de Pós-Graduação em Ciência da Informação da UFMG. Docente na Escola de Biblioteconomia da UNIRIO. Email: viniciustollentino@gmail.com.
}

Inf. Inf., Londrina, v. 22, n. 2, p. 166 - 207, maio/ago., 2017. http:www.uel.br/revistas/informacao/ 


\section{INTRODUÇÃO}

A motivação de abordar o tema mulher justifica-se pelo modo como, nos últimos tempos, esse assunto tem desencadeado transformações que precisam ser compreendidas pelas formas da completude da Organização do Conhecimento $(\mathrm{OC})$, envolvendo tanto o aspecto temático quanto descritivo. Portanto, torna-se necessário repensar os instrumentos documentários e a ação não pode estar desvinculada do contexto social, pois os limites e as definições acerca do tema são flexíveis e estão situados em zona de tensão social e desigualdade, necessitando de discussões.

Em busca de uma abordagem aplicada, o trabalho analisa algumas dimensões da representação da mulher em três instrumentos documentários, sendo o Tesauro para Estudos de Gênero e sobre Mulheres (TEG), o Tesauro Jurídico do Superior Tribunal de Justiça (TJ STJ) e o Anglo American Cataloguing Rules, $2^{\mathrm{a}}$ edição (AACR2r), conhecido no Brasil como Código de Catalogação Anglo-Americano (CCAA2).

A escolha dos três instrumentos para discussão vincula-se ao fato da utilização frequente em bibliotecas e, se compreende que a construção do registro bibliográfico, deve envolver questões que abarquem a temática gênero. Ademais, a estratégia de criação desses registros envolve a produção de conhecimento estruturado em garantias que sustentam o fazer da representação.

Como forma prescritiva de rotulagem, portanto de aplicação do que consta nos instrumentos documentários, a representação percorre a delimitação, a extirpação das possibilidades de sentidos e os direcionamentos de descritores e regras definem aspectos que, por vezes, desencadeia o apagamento do tema mulher ou o inferioriza, em relação ao homem.

Nesse sentido, a consequência do uso dos referidos instrumentos é observada na busca e recuperação da informação. O impacto do resultado, quer seja uma representação imbuída de preconceitos, quer seja pelo fato do instrumento não ser atualizado ou por desconhecimento do profissional em relação ao domínio, surtirá na comunidade usuária. Para que não se

Inf. Inf., Londrina, v. 22, n. 2, p. 166 - 207, maio/ago., 2017. 
perpetuem representações machistas, sexistas e misóginas em catálogos ou bases de dados, por exemplo, torna-se imprescindivel que os profissionais tenham um olhar crítico sobre as ferramentas que utilizam.

\section{DELINEAMENTOS HIERARQUIZADORES PARA INSTRUMENTOS DOCUMENTÁRIOS}

A estruturação de regras, o controle e a vinculação hierárquica são caraterísticas prementes dos instrumentos documentários, que se estruturam a partir de princípios significativos para emoldurar sentido na representação documentária. Esses instrumentos são caracterizados como sistemas de organização do conhecimento e se intitulam listas de cabeçalhos de assunto, tesauros, tabelas de classificação, códigos de catalogação, dentre outros.

Em paralelo ao contexto documentário, a capacidade humana de elencar, estruturar e classificar ideias, atividades e objetos são inatos à predisposição intelectual. "Na verdade, nada nos parece mais 'natural', óbvio e indiscutível que as classificações dos entes, dos factos e dos acontecimentos que constituem os quadros mentais em que estamos inseridos." (POMBO, 1988, p. 1).

Ainda segundo a autora supracitada, são construídos padrões e hábitos que nos auxiliam a reconhecer lugares, seres e acontecimentos e, para isso, ordenamos, agrupamos e aproximamos ou afastamos essas experiências. Acredita-se que a necessidade de fixar e moldar o que vivenciamos se entrelaça com os instrumentos documentários, pois esses normatizam, buscam fixar e retratar uma dada realidade, a fim de corroborar no processo de representação, pois tais instrumentos funcionam como tradutores das unidades informacionais apresentadas pela forma e conteúdo dos documentos. Nesse sentido,

[...] são, como diz Foucault (1966: 10), os "códigos ordenadores" da nossa cultura. Códigos fundamentais de todas as culturas, não no sentido vulgarmente sociológico e relativista de instituições que variam de uma "idade" para outra, de uma "geografia" para outra, mas como aqueles que "fixam logo á entrada, para cada homem, as ordens empíricas com que ele

Inf. Inf., Londrina, v. 22, n. 2, p. 166 - 207, maio/ago., 2017.

http:www.uel.br/revistas/informacao/ 
terá que lidar e em que se há-de encontrar" (Foucault, 1966: 8), solos epistémicos "onde os próprios conhecimentos enraízam a sua possibilidade" (Foucault, 1966: 10) e onde o olhar minucioso, descritivo, hierarquizador e relacional que torna possível a constituição de todos os saberes encontra o seu próprio princípio de instituição. (POMBO, 1988, p. 2).

No contexto documentário é possível encontrar vários tipos de instrumentos que buscam "o olhar minucioso, descritivo, hierarquizador e relacional" citados acima e, destacamos dois, a saber: o tesauro e o AACR2r.

De acordo com Novellino (1996, p. 39), “a preocupação com a criação de um instrumento de representação da informação voltado para a recuperação e, consequentemente, para demonstrar ao usuário a estrutura da linguagem de representação deu origem aos tesauros [...]". Cervantes e Fujita (2012) indagam sobre a origem do tesauro e apontam que sua evolução histórica não direciona apenas uma resposta sobre o seu aparecimento, mas para fatores de diferentes épocas, lugares e teorias que ocasionaram o movimento histórico do instrumento.

Por consequência, criam-se representações e, a partir delas, são utilizados instrumentos documentários para controle e posterior auxílio de busca e recuperação da informação documentária. Portanto, instaura-se um processo comunicativo e, de acordo com Mey (1995, p. 3, destaque da autora),

[...] O processo de comunicação na biblioteca deve abranger dois ângulos: o ponto de vista do item e o ponto de vista do usuário. Trata-se de uma via de mão dupla.

Uma vez que não se mostram aos usuários os itens em si, mas suas representações, nossas mensagens utilizam códigos, que repousam sobre outros códigos, isto é, códigos denominados conotativos. Por exemplo, 1984 pode significar uma data de publicação, o número de páginas de um livro, o título de uma obra ou o pseudônimo de um autor. O que faz a diferença entre as diversas informações é a posição em que se encontra o código utilizado [...].

Conforme a exposição de Mey (1995) é possível constatar que a ordem e a posição na representação da informação documentária direcionam significados que podem reverberar conotações em diferentes dimensões, inclusive em relação à representação da mulher.

Inf. Inf., Londrina, v. 22, n. 2, p. 166 - 207, maio/ago., 2017. http:www.uel.br/revistas/informacao/ 
Tais fatos direcionam a compreensão dos instrumentos documentários não serem estanques, necessitando que se façam leituras e aprofundamentos em suas estruturas. Entretanto, o seu estabelecimento carrega questões basilares que vão ao encontro dos seguintes pontos:

1) toda a classificação das ciências supõe um agente classificativo [...]; 2) cada classificação das ciências tem por detrás um determinado mecanismo classificador que, melhor ou pior, executa as operações necessárias à classificação [...]; 3) toda a classificação das ciências supõe um princípio de classificação [...]; 4) toda a classificação das ciências persegue uma multiplicidade de fins [...]; 5) a classificação das ciências exerce-se sobre um conjunto de elementos finitos, as ciências constituídas ou em vias de constituição. Não sobre todo o conjunto das ciências possíveis, mas tão só sobre o conjunto das ciências constituídas numa determinada época ou nela já previsíveis [...]; 6) cada classificação das ciências constroi-se no contexto das classificações precedentes, isto é, implica, não apenas uma dimensão sincrónica, uma sistemática dos saberes constituídos na época, como também uma dimensão diacrónica, ou seja, integra-se no contexto da história das classificações das ciências; 7) para cada classificação das ciências existe um produto externo da actividade classificadora, tanto em termos da constituição de uma nomenclatura como da produção de sistemas diagramáticos de articulação das ciências. (POMBO, 1988, p. 5, destaque da autora).

Segundo as vinculações propostas por Pombo (1988) é possível observar aproximações com a estruturação do tesauro e do AACR2r, pois ambos como instrumento documentário de controle, possuem na sua essência ao menos um ou vários agentes e mecanismo e um princípio norteador; ao menos um fim determinístico e elementos de um domínio, tendo por base classificações ou fatos antecedentes que sustentados por um novo olhar resultarão em um produto externo, portanto, representações controladas.

Todavia, conforme direciona Pombo (1988, p. 2), "[...] não discutimos as classificações a partir das quais o nosso próprio discurso se constrói." Cabe então ressaltar o ponto central que baliza a formalização dos instrumentos documentários: o próprio discurso, que valide o domínio a ser representado ou discursos outros imbricados pela escassez de reflexão sobre o domínio.

É importante considerar que os instrumentos documentários devem ser analisados e questionados sem naturalizações e, como peças dinâmicas,

Inf. Inf., Londrina, v. 22, n. 2, p. 166 - 207, maio/ago., 2017. http:www.uel.br/revistas/informacao/ 
comtempladas temporal e espacialmente desencadeiam atividades reflexivas sobre as possíveis propostas de representações. Portanto, necessita passar por revisão contínua, caso contrário poderá estar fadado a um amontoado de palavras.

Assim, o propósito deste trabalho consiste no enfrentamento do olhar machista disposto nos instrumentos documentários, considerando o enfoque fronteiriço a ser analisado, a partir da representação da mulher.

Para balizar a posição por ora assumida, toma-se a definição de feminismo como "[...] movimento e um conjunto de teorias que têm em vista a libertação da mulher. Esse movimento nasceu nos Estados Unidos, na segunda metade da década de 1960, e se desenvolveu rapidamente por todos os países industrialmente avançados, entre os anos 1968 e 1977." (BOBBIO; MATTEUCI; PASQUINO, 2010, p. 485).

Segundo os referidos autores, o termo libertação contrapõe-se ao conceito de emancipação, que o feminismo contemporâneo firmou na fase extrema do século XIX e, concomitante, fixou-se pela superação. Em relação à emancipação, sua luta baseou-se na busca da igualdade, tanto no aspecto jurídico, quanto político e econômico em relação ao homem, entretanto, se manteve na dimensão dos valores masculinos reconhecidos e aceitos. Já o conceito de libertação atrela-se ao de igualdade para declarar a mulher como "[...] assunção histórica da própria alteridade e busca de valores novos para uma completa transformação da sociedade." (BOBBIO; MATTEUCl; PASQUINO, 2010, p. 485).

Visando contribuir com essa transformação, pautando-se na OC, na próxima seção delinear-se-á o panorama para enfrentar o predomínio de valores machistas, especificamente no contexto dos instrumentos documentários.

\section{A QUESTÃO DA MULHER NA ORGANIZAÇÃO DO CONHECIMENTO}

Diferentes abordagens estão vinculadas ao estudo de gênero e se observa que a expansão das pesquisas deteve-se, sobretudo, em áreas como

Inf. Inf., Londrina, v. 22, n. 2, p. 166 - 207, maio/ago., 2017. http:www.uel.br/revistas/informacao/ 
História e Ciências Sociais. Entretanto, a referida temática é abrangente e a presença das mulheres em diferentes espaços é motivação e ponto das agendas de pesquisa sobre o assunto.

Pinsky (2009) revela ser pequena a quantidade de trabalhos na área de História no Brasil que utilizam o conceito de gênero. A autora reforça que a partir da década de 1970 houve proliferação de questionamentos feministas com temas envolvendo família, sexualidade e representação de grupos, com aderência aos avanços da Nouvelle Histoire, Social History, Cultural History e dos Estudos de População.

Focando em questões nacionais, Sarti $(2001$, p. 32) indica que:

\begin{abstract}
O atual feminismo brasileiro nasce, nos anos 70 , no panorama internacional que instituía o Ano Internacional da Mulher (1975), favorável, portanto, à discussão da condição feminina e, ao mesmo tempo, no amargo contexto das ditaduras latinoamericanas, que calavam, implacáveis, as vozes discordantes. O retorno a esta origem, naquele momento e naquele contexto político, nos remete à radicalidade posta na questão da mulher como uma questão fundamentalmente "conflituosa", tanto nas relações entre o homem e a mulher, quanto em todas as relações de poder socialmente instituídas, articulando gênero e classe, como foi tantas vezes sublinhado sobre o caráter deste movimento, no Brasil.
\end{abstract}

Destaca-se que o movimento feminista no país teve influência e se fortaleceu na resistência das mulheres à ditadura militar e, inclusive, nos anos 1960 e 1970 a presença feminina na luta armada implicou violação ao que era designado como próprio às mulheres (SARTI, 2001). Sendo assim, o contexto de militância feminina ultrapassou o comportamento sexual da virgindade, a aceitação e manutenção do casamento vinculado ao papel de esposa, mãe e dona de casa que a sociedade instituiu como de responsabilidade exclusiva da mulher.

Nessa condição, Corrêa (2001) elucida que grande parte das mulheres no contexto brasileiro que se tornaram feministas passaram pela França e pelos Estados Unidos no início dos anos 1970 e, consequentemente, as verbas de pesquisa para a temática mulher chegaram de fundações norte-americanas. $O$ incentivo financeiro do exterior para pesquisas nacionais, como o 
dimensionou a Fundação Carlos Chagas, nas rubricas do Women's Studies e Educação, recebeu dotações orçamentárias da Ford, entre 1962 e 1992. Também foi concedido subsídio menor à Pontifícia Universidade Católica do Rio de Janeiro (PUC-RJ) e as pesquisas do Centro Brasileiro de Análise e Planejamento (CEBRAP).

Levando em consideração a Fundação Carlos Chagas, Corrêa (2001) aponta que a instituição teve grande concentração de profissionais preocupadas com a situação da mulher e, inclusive, foi responsável pela elaboração do Tesauro para Estudos de Gênero e sobre Mulheres (TEG), um dos instrumentos escolhidos para ser analisado nessa pesquisa ${ }^{1}$.

Ampliando o olhar sobre os aspectos da presença feminina na sociedade, vinculam-se como prementes as noções da divisão de trabalho e bens, pois nesse aspecto se tem a conceituação de família ou sistema patriarcal. Foi com o crescimento da cultura de polarização de sexos que o termo machismo pode ser entendido, segundo Castañeda (2006, p. 16) como:

um conjunto de crenças, atitudes e condutas que se repousam na compreensão da polarização dos sexos, da contraposição do feminino e masculino não apenas como diferentes, mas como mutuamente excludentes, onde o masculino é representado como superior.

Historicamente, a humanidade compreendeu de modo diverso distintas definições sobre o lugar social da mulher variando de cultura para cultura, composições geográficas e outras diferentes perspectivas. Logo, entende-se que o lugar social da mulher perpassa inúmeros desdobramentos que diversamente compuseram comportamentos, dispositivos legais e manifestações ideológicas. Com isso,

a produção historiográfica passível de ser reunida sob o título História das Mulheres foi e é bastante diversificada em termos de assuntos, métodos e qualidade intelectual. Entretanto, esses trabalhos têm em comum: a atenção às mulheres do passado e o reconhecimento de que a condição feminina é constituída histórica e socialmente. (PINSKY, 2009, p. 159).

Inf. Inf., Londrina, v. 22, n. 2, p. 166 - 207, maio/ago., 2017. http:www.uel.br/revistas/informacao/ 
O aspecto da justificativa cristã, no que pese o homem ter recebido primeiro o sopro da vida e, após, de sua costela ter vindo à mulher desencadeia característica de subordinação. Não sem propósito, a lógica social fundamentada no capitalismo ocidental apresentou caraterísticas peculiares a respeito da mulher, como aquela que, conforme influência religiosa cristã apontou ser a responsável em gestar, parir e cuidar. Já o homem se consolidou pela força física, como o chefe da família e provedor.

No questionamento das desigualdades, os estudos de gênero provocou novo olhar sobre o papel das construções sociais, influenciando a visão sobre as origens de identidades impostas abarcando, assim, a temática mulher.

A dimensão a ser pensada para esse trabalho centra na aproximação da representação da mulher e o desvelamento de contradições machistas em três instrumentos documentários e almeja destacar a compreensão do processo contínuo de machismo refeito culturalmente também nos instrumentos documentários.

No contexto brasileiro, destacam-se dois trabalhos referentes aos aspectos da mulher na OC, a saber, Milani (2010) e Moraes (2014). Em pesquisa de mestrado, Milani (2010) investigou problemas de biasses na representação da informação, envolvendo categorizações dicotômicas e falta de garantia e hospitalidade cultural no tocante à questão da mulher. Como referencial teórico utilizado pela autora destacam-se Caro Castro e San Segundo Manuel (1999)², Olson (2002, 2003)33 , López-Huertas, Torres e Barité $(2004)^{4}$, López-Huertas Pérez e Torres Ramírez (2005)5.

Segundo Milani (2010, p. 14) o termo original bias em inglês (correspondente a sesgos, em espanhol) "abrange os sentidos de tendência, viés, inclinação, desvio, uma vez que não se encontra, em língua portuguesa, termo que dê conta de todo o conteúdo relativo a bias." Milani (2010, p. 14) destaca que a representação do conhecimento, a partir de linguagens documentárias, visa disponibilizar informações aos usuários, atuando de forma a que todas as pessoas, sem distinção, se sintam refletidos nessa realidade. A referida autora, com base em Olson $^{3}$, sinaliza que tais representações

Inf. Inf., Londrina, v. 22, n. 2, p. 166 - 207, maio/ago., 2017. http:www.uel.br/revistas/informacao/ 
correspondem a substitutos do conhecimento, pois um rótulo é construído, não sendo isento das biasses.

Já Moraes (2014) relaciona os aportes metodológicos na construção de Sistemas de Organização do Conhecimento (SOC) e analisa as contradições apresentadas na elaboração do Tesauro para Estudos de Gênero e sobre Mulheres (TEG). Por conseguinte, o foco centrou na constituição do instrumento.

É fato que a mulher deve estar presente nos instrumentos documentários e compreender como procede a sua representação deve ser pauta de investigações no contexto da OC. Portanto, o olhar dado a este trabalho objetiva colaborar com as discussões que envolvem mulher, machismo e instrumentos documentários.

\subsection{A Estrutura dos Instrumentos Documentários Selecionados}

As representações documentárias adotadas por bibliotecas e centros de documentação outorgam regras, códigos e procedimentos específicos para descrever as informações contidas nos documentos e as opções atribuídas condicionam o teor representacional.

No decorrer dos anos, a OC enfrentou desafios significativos que, de acordo com Ortega (2012), a qualificaram quanto aos aportes linguísticos e terminológicos, e sustentaram o conjunto de teorias, metodologias e construções dos instrumentos documentários. Esses últimos são utilizados por processos decorrentes de intervenções sobre o documento, que são compreendidos pela análise e representação do conteúdo e da forma documental para fins de busca e recuperação por parte da comunidade usuária.

Guinchat e Menou (1994) explicitam que a atividade de concepção e desenvolvimento de normas é algo construído coletivamente e gerado com o propósito de simplificar, racionalizar e unificar os produtos dos processos documentais. "As normas podem ser de natureza material, ou seja, quantificáveis, ou de natureza intelectual, por exemplo, uma definição"

Inf. Inf., Londrina, v. 22, n. 2, p. 166 - 207, maio/ago., 2017. http:www.uel.br/revistas/informacao/ 
(GUINCHAT; MENOU, 1994, p. 434), compreendidas em pelo menos quatro tipologias: dimensão; qualidade; definição; e procedimentos e métodos.

As tipologias das normas são entendidas por suas aplicabilidades que, de acordo com os autores, são compostas como: "dimensão", abarca o tamanho e/ou extensão de equipamentos; "qualidade", evidenciada pela característica das propriedades dos objetos; "definição", entendida por normas de vocabulários, termos e símbolos; e "procedimentos e métodos", engloba a utilização de certos objetos, como também normas ou princípios relativos à elaboração de instrumentos documentários (GUINCHAT; MENOU, 1994).

A tipologia "procedimentos e métodos", compreendida pelo conjunto de normas utilizadas para descrição dos conteúdos informacionais, com a finalidade de elaborar catálogos e registros bibliográficos, foi selecionada para análise. $O$ recorte centrado nas normas privilegiou dois instrumentos: dois tesauros e o código de catalogação.

O tesauro tem a função de controle e, por consequência, a representação dos documentos visando à recuperação. Assim, também se torna um meio de comunicação entre acervo e usuário, pois o instrumento cria pontos de substituição sobre o conteúdo do documento.

No referido instrumento, o conceito é o que sustenta a criação dos descritores, que são palavras ou expressões que direcionam o termo preferido para o processo de representação temática, denominado indexação. A estruturação do instrumento abrange várias relações entre os descritores, tendo assim a função de controlar o vocabulário de um domínio específico.

Gomes (1990, p. 14) aponta que:

O tesauro documentário surgiu da necessidade de manipular grande quantidade de documentos especializados. Era preciso trabalhar com vocabulário mais específico e com uma estrutura mais depurada do que aquela presente nos cabeçalhos de assunto (remissivas e referências cruzadas tipo ver e ver também). Assim, além da especificidade, cuidou-se de melhorar a estrutura e as referências cruzadas (ver também) deram lugar às relações hierárquicas (vertical) e associativas (horizontal).

Inf. Inf., Londrina, v. 22, n. 2, p. 166 - 207, maio/ago., 2017. 
Dessa forma, o uso dessa linguagem documentária tem como função possibilitar a intermediação entre os documentos e os usuários, entretanto, não é um processo isolado. Sendo assim, a busca por meios conceituais hegemônicos deve ser o ponto central e norteador dos professionais que elaboram esses instrumentos, pois a ação desencadeia, por exemplo, categorias de dominação.

Considera-se que os tesauros são instrumentos específicos e torna-se compreensível que um mesmo descritor possa ser representado de forma hierárquica diferente, pois dependerá do domínio de inserção. Entretanto, para apresentação de um descritor é essencial levar em consideração três pontos fundamentais: a garantia literária, a garantia de uso e a garantia estrutural (MOREIRA, 2005).

A garantia literária sugere que os descritores devem se originar com base na literatura e, deste modo, o termo escolhido aqui é derivado da própria literatura que pautará o instrumento. A garantia do usuário, como o próprio nome sugere, parte do princípio que os termos selecionados para um tesauro precisam estar de acordo com os utilizados pela comunidade usuária na recuperação de informação. Já a garantia estrutural decorre quando os termos não são nem da garantia literária e tão pouco da garantia do usuário. São termos que facilitam elos em uma hierarquia/estrutura ou colaboram para que seja possível dispor um conjunto mais específico de termos (MOREIRA, 2005).

Fujita (2011) direciona que para a construção e normalização de tesauros existem normas que balizam o trabalho, como as diretrizes para construção de tesauros monolíngues do Instituto Brasileiro de Informação em Ciência e Tecnologia (1984), as diretrizes da UNESCO (DEREK; PETER, 1993) e a norma ANSI Z39.19 (AMERICAN NATIONAL STANDARDS INSTITUTE; NATIONAL INFORMATION STANDARDS ORGANIZATION, 2005). Todavia, o foco deste trabalho não é a construção, mas sim a análise instrumental com recorte determinado.

Para fundamentar, faz-se necessário destacar as principais características dos tesauros: os termos e as relações existentes entre eles (GOMES, 1990). Sendo assim, os relacionamentos possíveis, de acordo com

Inf. Inf., Londrina, v. 22, n. 2, p. 166 - 207, maio/ago., 2017. http:www.uel.br/revistas/informacao/ 
Brisa Pozzi de Sousa, Vinicius de Souza Tolentino

Aspectos machistas na organização do conhecimento: a representação da mulher em instrumentos documentários

Instituto Brasileiro de Informação em Ciência e Tecnologia (1984) seguem indicados no quadro 1.

Quadro 1 - Características dos Tesauros: termos e relações

\begin{tabular}{|l|l|}
\hline \multicolumn{1}{|c|}{ TERMOS } & \multicolumn{1}{c|}{ SIGNIFICADOS } \\
\hline TG (Termo Genérico) & $\begin{array}{l}\text { O descritor representa um conceito de conotação } \\
\text { mais ampla. }\end{array}$ \\
\hline TGM (Termo Genérico Maior) & $\begin{array}{l}\text { O descritor é o nome mais genérico da classe a que } \\
\text { pertence o termo específico. }\end{array}$ \\
\hline TGP (Termo Genérico Partitivo) & O descritor representa o todo em relação à parte. \\
\hline TE (Termo Específico) & $\begin{array}{l}\text { O descritor representa um conceito de conotação } \\
\text { mais específica. }\end{array}$ \\
\hline TEP (Termo Específico Partitivo) & O descritor representa a parte em relação ao todo. \\
\hline TO (Termo Oposto) & $\begin{array}{l}\text { O descritor representa um conceito contrário, } \\
\text { contraditório, oposto. }\end{array}$ \\
\hline TA (Termo Associado) & $\begin{array}{l}\text { O descritor representa um conceito ligado por } \\
\text { associações outras que não as genéricas, partitivas } \\
\text { e/ou de oposição. }\end{array}$ \\
\hline UP (Usado para) & Descritor, termo preferido. \\
\hline Use &
\end{tabular}

Fonte: Instituto Brasileiro de Informação em Ciência e Tecnologia (1984, p. 6).

Nessa conjuntura, um descritor pode estar relacionado a vários outros e as ligações são estabelecidas pelas siglas indicadas. Gomes (1990, p. 57) aponta que a forma alfabética é a tradicional de apresentação. A esquematização da estruturação dos descritores segue no quadro 2.

Quadro 2 - Estruturação de Descritores dos Tesauros

\begin{tabular}{|l|c|}
\hline \multicolumn{1}{|c|}{ Termo } & Código \\
\hline Nota de aplicação & - \\
\hline Equivalências & UP \\
\hline Termo genérico & TG \\
\hline Termo genérico partitivo & TGP \\
\hline Termo(s) específico(s) & TE \\
\hline Termo(s) específico(s) partitivo(s) & TEP \\
\hline Termo(s) associado(s) & TA \\
\hline
\end{tabular}

Fonte: Gomes (1990, p. 57).

Voltando-se ao instrumento descritivo, o Código de Catalogação é entendido pelo conjunto de regras baseadas na experiência e regida por princípios gerais que resolvam problemas referentes à descrição formal dos documentos. Os códigos não estão destinados somente a fornecer regras para eleger a maneira de representar o autor de um documento, mas orientam processos para elaboração de um registro bibliográfico, assegurando coesão e

Inf. Inf., Londrina, v. 22, n. 2, p. 166 - 207, maio/ago., 2017. http:www.uel.br/revistas/informacao/ 
uniformidade nos catálogos. Os códigos definem as características de um procedimento sobre determinado trabalho intelectual materializado em algum suporte.

Muitos países constituíram comissões de profissionais encarregadas de criar normas e regras de descrição. O Código de Catalogação AngloAmericano $2^{a}$ edição (CCAA2r, ou, AACR2r a partir da sigla em inglês) é utilizado, é mundialmente conhecido e adotado em vários países.

Como o título do instrumento indica, observa-se a predominância da produção intelectual e do pensamento anglo-americano. O fato pode ser explicado, em certa medida, pelo reconhecimento dos estudos de Panizzi ${ }^{6}$, no século XIX, como sendo um dos primeiros a configurar um modo de consolidação de princípios para a Catalogação. Entretanto, não é possível dimensionar a fundamentação do referido instrumento, pois sua estruturação envolveu econômicos da catalogação centralizada que incluía o uso de tecnologias para a reprodução de fichas catalográficas.

De fato, segundo Malinconico (1977), já em 1898, a Library of Congress (LC) passou a produzir fichas catalográficas impressas de seu acervo e, em 1901, três anos depois, Herbert Putnam, bibliotecário da LC, inaugurou um programa que fazia cópias de fichas para outras bibliotecas nos Estados Unidos. Essa tecnologia foi um importante evento na era moderna de padronização do controle bibliográfico.

A partir da iniciativa de criação de universidades em outros países, os Estados Unidos encaminhavam regularmente pessoas para se profissionalizarem ou se aperfeiçoarem em universidades americanas e inglesas, principalmente oriundas de países onde não existiam escolas de Biblioteconomia (BARBOSA, 1978).

Apesar do ineditismo no processo de aplicação tecnológica na catalogação, a LC passou a questionar seu trabalho constatando que a compilação das regras não era realizada de modo sistemático e, além disso, estavam ultrapassadas (LIBRARY OF CONGRESS, 1956).

A comunidade norte-americana sentiu os efeitos de quase meio século de dependência da catalogação da Library of Congress e, os problemas

Inf. Inf., Londrina, v. 22, n. 2, p. 166 - 207, maio/ago., 2017. http:www.uel.br/revistas/informacao/ 
referentes à forma cooperativa, eram evidenciados quando os(as) bibliotecários(as) tentavam se guiar pela técnica de catalogação (da LC) e percebiam que desconheciam as regras em que se baseavam suas práticas (LIBRARY OF CONGRESS, 1956; GORMAN, 1982).

Nesse cenário, a primeira edição do código foi publicada em 1967 e realizada em conjunto com a American Library Association (ALA), a Canadian Library Association e a Library Association (Inglaterra) (BARBOSA, 1978).

A segunda edição, em 1978, incorporou os estudos da International Standard Bibliographic Description (ISBD) ${ }^{7}$, a qual determina os elementos de dados a serem registrados ou transcritos em uma ordem específica para a descrição do item que será catalogado, utilizando uma pontuação com o intuito de facilitar a comunicação internacional das informações bibliográficas (DESCRIÇÃO..., 2012). A ISBD serviu de base para construção de códigos ou regras de catalogação em todo o mundo e é o formato que estrutura o atual Código de Catalogação vigente.

Destarte, feito o panorama dos instrumentos, na próxima subseção apresentar-se-á os que compuseram a análise da pesquisa. A opção de escolha pelo Tesauro de Gênero e sobre Mulheres (TEG) decorre ao fato de ser o único em território nacional que cobre especificamente o domínio mulher.

Quanto ao segundo instrumento selecionado, o tesauro do Superior Tribunal de Justiça (TJ STJ), deve-se a abrangência que o STJ tem enquanto "Tribunal da Cidadania", "responsável pela solução de conflitos da sociedade e garantia de direitos dos cidadãos." (BRASIL, [200?a], on-line). Constata-se a importante função da Instituição perante a sociedade brasileira e, portanto, a inquietação em investigar como descritores que envolvem mulher são estruturados no referido instrumento.

Por fim, a escolha do terceiro instrumento consiste no fato do AACR2r ser amplamente utilizado no Brasil, pois não há um código nacional.

Inf. Inf., Londrina, v. 22, n. 2, p. 166 - 207, maio/ago., 2017. http:www.uel.br/revistas/informacao/ 
3.1.1 Instrumentos temáticos: Tesauro para Estudos de Gênero e sobre Mulheres (TEG) e Tesauro Jurídico do Superior Tribunal de Justiça (TJ STJ)

O primeiro instrumento escolhido para análise é o tesauro para Estudos de Gênero e sobre Mulheres (TEG) que utiliza a seguinte estruturação:

[...] cada termo com a sua ascendência até o termo genérico, Broader Term (BT), com a sua descendência de termos específicos, Narrower Term (NT), com as suas ligações com termos relacionados, Related Term (RT), e indica também os termos cujo uso é recomendado, Used (USE) ou aqueles que devem ser substituídos, Used for (UF) (BRUSCHINI; ARDAILLON; UNBEHAUM, 1998, p. 20, destaque das autoras).

Uma observação deve ser feita em relação à sigla SG que equivale a Subject Groups, que são áreas temáticas adotadas pelo $A$ Women's Thesaurus $(A W T)^{8}$ "[...] para estruturar 'o estudo das relações sociais entre homens e mulheres'. Essas áreas representam categorias, ou facetas, ou ainda aspectos particulares desse campo de conhecimento dentro dos quais se agrupam diversas classes de assuntos." (BRUSCHINI; ARDAILLON; UNBEHAUM, 1998, p. 17). Portanto, para ilustrar parte dos relacionamentos e da estruturação, segue o exemplo de um descritor retirado do TEG.

Figura 1 - Descritor do TEG

\begin{tabular}{|c|}
\hline \multicolumn{2}{|c|}{ crimes contra mulheres } \\
SG Ciências Sociais e Cultura \\
Lei, Governo e Políticas \\
Públicas \\
BT crimes \\
RT crime \\
crimes sexuais \\
estupro \\
incesto \\
prostituição \\
violência contra mulheres \\
violência doméstica
\end{tabular}

Fonte: Bruschini, Ardaillon e Unbehaum (1998, p. 55).

Além disso, o tesauro supracitado possui a "[...] função eminentemente didática de difundir uma linguagem menos sexista que permita apreender um

Inf. Inf., Londrina, v. 22, n. 2, p. 166 - 207, maio/ago., 2017. http:www.uel.br/revistas/informacao/ 
mundo menos discriminatório em relação às mulheres." (BRUSCHINI; ARDAILLON; UNBEHAUM, 1998, p. 13).

É possível notar que o rigor metodológico também é substancial, entretanto, a percepção e análise do domínio que o tesauro abarca se torna crucial. Assim, a necessidade por um instrumento propiciador de acesso a informações sobre a condição feminina e eventuais mapeamentos dos estudos de gênero desencadeou a criação do TEG. Portanto,

No Brasil, o desenvolvimento científico do campo ocorreu nos últimos vinte anos com características peculiares. De fato, ele acompanhou a própria legitimação do "feminismo", tido como ideologia de classe média, dentro do "movimento de mulheres", este amplamente aceito como mais um dos movimentos envolvidos no processo de redemocratização política. Atribuiuse assim à área de estudos de gênero a denominação "de Mulher", ou "sobre Mulher", outorgando à palavra "Mulher", além do sentido de uma discutível identidade feminina genérica, a própria definição de uma área do saber, o que teve várias consequências. (BRUSCHINI; ARDAILLON; UNBEHAUM, 1998, p. 13-14).

Em relação ao segundo instrumento temático escolhido, o Tesauro Jurídico, também denominado Vocabulário Jurídico Controlado, é gerenciado pela Secretaria de Jurisprudência do Superior Tribunal de Justiça. Consiste em uma lista de termos jurídicos baseada na conexão das relações estabelecidas entre esses (BRASIL, [200?b]).

Sua estruturação tem por base as relações de equivalência, hierárquica, polierarquia e associativa, sendo composto de descritores, não-descritores e modificadores:

- Descritores: são termos simples ou compostos (substantivos ou frases substantivadas) autorizados pelo tesauro para representarem conceitos e proporcionar recuperação de informação, optando-se por utilizar a terminologia usualmente empregada pelos ministros, selecionada dos acórdãos incluídos na base de dados da jurisprudência do STJ;

- Não-Descritores: são termos que, embora representem os mesmos conceitos que os descritores, não são autorizados para uso no tratamento da informação, servindo apenas para indicar sinonímia no intuito de facilitar a recuperação da

Inf. Inf., Londrina, v. 22, n. 2, p. 166 - 207, maio/ago., 2017. http:www.uel.br/revistas/informacao/ 
informação, em especial na página de Pesquisa de Jurisprudência onde há a opção de se realizar a pesquisa por sinônimos. Esses termos são representados pela indicação de termo correspondente, através da anotação USE;

- Modificadores: são termos autorizados pelo tesauro e utilizados para modificar ou complementar o descritor principal. Os modificadores tiveram muita importância quando se fazia a indexação dos documentos e, também, quando se evoluiu para o resumo estruturado e, depois, para as informações complementares. (BRASIL, [200?b], on-line).

Sendo assim, apresenta-se o exemplo de um descritor extraído do Tesauro Jurídico do STJ (TJ STJ) na figura 2.

Figura 2 - Descritor do Tesauro do STJ

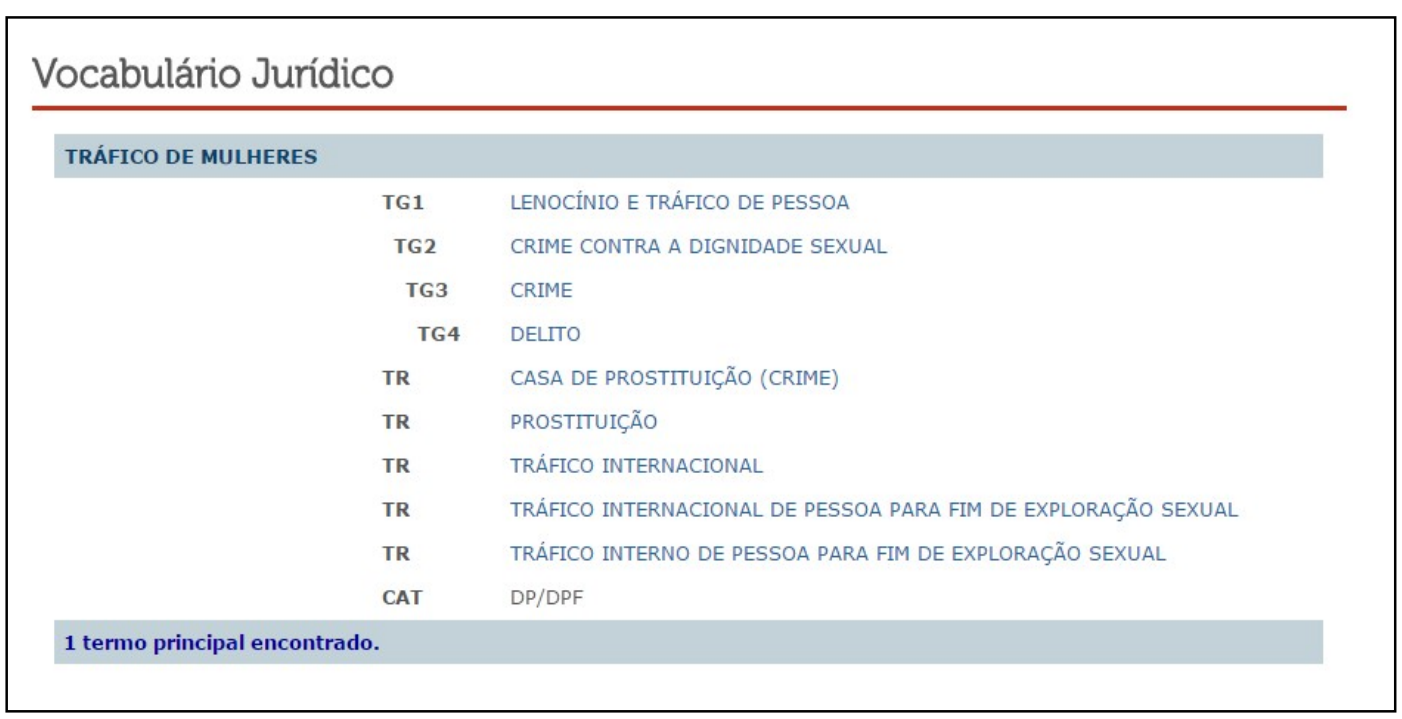

Fonte: Brasil ([200?b], on-line).

De acordo com o TJ STJ, os descritores embasados pela Relação de Equivalência são estabelecidos entre termos sinônimos ou equivalentes, sinalizado pela palavra USE. Para o que não for descritor, portanto nãodescritor, emprega-se a sigla UP (Uso Proibido). A Relação Hierárquica designa os níveis de superordenação e subordinação entre os conceitos e o primeiro nível é expresso pelo TG (Termo Genérico) representando também conceitos abrangentes (TG1, TG2, TG3, TG4). A Polierarquia permite que um TE (Termo Específico) se relacione diretamente com mais de um TG, e a Relação Associativa é desencadeada entre termos que não são equivalentes

Inf. Inf., Londrina, v. 22, n. 2, p. 166 - 207, maio/ago., 2017. http:www.uel.br/revistas/informacao/ 
nem hierárquicos, mas estão associados. Assim, o símbolo TR ilustra tal relação (BRASIL, [200?b], on-line).

3.1.2 Instrumento descritivo: Anglo-American Cataloguing Rules, Second edition - AACR2r

O AACR2r foi adotado por muitos países, como o Brasil. Os trabalhos realizados pela bibliotecária Maria Luísa Monteiro da Cunha, da Universidade de São Paulo (USP), foram primordiais para o debate sobre a confecção de um possível código de catalogação nacional com base na ISBD. A referida bibliotecária divulgou a proposta junto às bibliotecas brasileiras e escolas de Biblioteconomia, ressaltando o fato negativo da adoção de princípios internacionais para o contexto brasileiro, ou seja, um instrumento que não reflete a identidade do país, entretanto, o projeto nacional infelizmente não prosperou.

A Federação Brasileira de Associações de Bibliotecários, Cientistas da Informação e Instituições (FEBAB), a partir de vários contatos realizados com a American Library Association, Library Association e Canadian Library Association, assinou em 11 de julho de 1980 o acordo que autorizou a FEBAB a publicar o AACR em língua portuguesa, efetivado em dois volumes, sendo em 1983 o volume 1 e, em 1985, o volume 2 (FEDERAÇÃO..., 2016).

Posteriormente, várias tentativas foram realizadas para reimpressão do código com as atualizações publicadas desde 1988, porém sem sucesso devido à insuficiência de recursos financeiros. Em janeiro de 2003, foi realizada a renovação do contrato com os editores do AACR para a cessão dos direitos autorais, o que possibilitou à FEBAB as providências para tornar disponível aos(as) bibliotecários(as) brasileiros(as) e dos países de língua portuguesa o novo Código de Catalogação Anglo-Americano, $2^{\mathrm{a}}$ edição, revisão 2002 (FEDERAÇÃO..., 2016).

Portanto, não havendo um código nacional no Brasil, o AACR2r foi e continua sendo o instrumento documentário adotado, e suas compilações de regras objetivam padronizar as descrições bibliográficas para documentos, além de dar diretrizes para a escolha e elaboração dos pontos de acesso. Tem

Inf. Inf., Londrina, v. 22, n. 2, p. 166 - 207, maio/ago., 2017. 
como característica fornecer regras catalográficas pela manifestação do item, assim sendo, o suporte físico, ocasionando a necessidade de definir o nível de descrição para cada material.

A estrutura do AACR2r está dividida em duas partes: a primeira trata da descrição bibliográfica de livros, folhetos, materiais cartográficos, manuscritos, música, gravações sonoras, filmes, microformas, recursos contínuos e análise; a segunda trata dos pontos de acesso para cabeçalhos de pessoas, nomes geográficos, entidades coletivas, títulos uniformes e remissivas, abrangendo a escolha desses pontos de acesso, além de cinco apêndices, a saber: A. Maiúsculas e Minúsculas, B. Abreviaturas, C. Numerais, D. Glossário, E. Artigos iniciais, F. Apêndice à tradução brasileira.

Na próxima seção, o estudo analisa a representação da mulher nos instrumentos selecionados e apresentamos, a saber, Tesauro para Estudos de Gênero e sobre Mulheres (TEG), Tesauro Jurídico do Superior Tribunal de Justiça (TJ STJ) e AACR2r.

\section{ASPECTOS PARA ANÁLISE DOS INSTRUMENTOS SELECIONADOS}

Pombo (1988), com base em Michel Foucault, elucida que códigos ordenadores estruturam nossa cultura. Eles nos fixam, direcionam as ordens e enraízam outras possibilidades de entender o mundo. Considerando que os instrumentos documentários seguem esse roteiro, se faz necessária uma discussão que paute o olhar para a representação da mulher.

Na letra da música "Mamãe", de composição de Herivelto Martins e David Nasser (1956), conduzida no embalo do bolero, é possível dimensionar a principal função de ser mulher na sociedade brasileira da primeira metade do século XX.

\section{Mamãe}

Ela é a dona de tudo,

Ela é a rainha do lar,

Ela vale mais para mim,

Que o céu, que a terra, que o mar,

Ela é a palavra mais linda,

Que um dia o poeta escreveu,

Inf. Inf., Londrina, v. 22, n. 2, p. 166 - 207, maio/ago., 2017.

http:www.uel.br/revistas/informacao/ 
Ela é o tesouro que o pobre, Das mãos do senhor recebeu, Mamãe, mamãe, mamãe, Tu és a razão dos meus dias, Tu és feita de amor e esperança, $\mathrm{Ai}$, ai, ai, mamãe, Eu cresci o caminho perdi volto a ti e me sinto criança mamãe, mamãe, mamãe, Eu te lembro chinelo na mão, O avental todo sujo de ovo, Se eu pudesse, Eu queria outra vez mamãe, Começar tudo, tudo de novo.

Tomando como ponto de referência o fato da mulher não ter reconhecimento único pela função matriarcal e que a luta é constante para redefinição do seu papel na sociedade, ressalta-se a observação de como a representação de vários descritores se estabelecem nos tesauros, pois esses instrumentos refletem diferentes aspectos, dentre eles os referentes à condição social.

O estudo não tem objetivo de ser exaustivo e a seleção dos descritores nos tesauros delimitou-se a observar representações machistas. Primeiro, deteve-se a questões vinculadas ao voto e a participação da mulher no cenário político, pois no Brasil houve ascensão da primeira mulher eleita presidenta da república em 2011, Dilma Rousseff, entretanto, infelizmente, a mesma foi destituída do cargo antes do término do segundo mandato. Em alusão a situação de uma mulher pela primeira vez ter alcançado o cargo máximo do país, a dúvida de como esse cenário pode ser representado no tesauro motivou a escolha.

Portanto, no Tesauro para Estudo de Gênero e sobre Mulheres (TEG), a análise centrou em 4 descritores: "cidadania", "cidadania das mulheres", "direitos das mulheres" e "participação política" (quadro 3).

Inf. Inf., Londrina, v. 22, n. 2, p. 166 - 207, maio/ago., 2017. http:www.uel.br/revistas/informacao/ 
Brisa Pozzi de Sousa, Vinicius de Souza Tolentino

Aspectos machistas na organização do conhecimento: a representação da mulher em instrumentos documentários

Quadro 3 - Descritores Tesauro para Estudo de Gênero e sobre Mulheres (TEG)

\begin{tabular}{|c|c|c|}
\hline DESCRITORES & & FORMA DE APRESENTAÇÃO \\
\hline CIDADANIA & $\begin{array}{l}\text { BT } \\
\text { NT } \\
\text { RT }\end{array}$ & $\begin{array}{l}\text { SG Ciências Naturais e Saúde } \\
\quad \text { Ciências Sociais e Cultura } \\
\quad \text { Lei, Governo e Políticas Públicas } \\
\text { política } \\
\text { cidadania das mulheres } \\
\text { assistência jurídica } \\
\text { civismo } \\
\text { direitos } \\
\text { educação } \\
\text { educação cívica } \\
\text { estado } \\
\text { imigração } \\
\text { naturalização } \\
\text { participação política } \\
\text { proteção ao consumidor } \\
\text { registro civil }\end{array}$ \\
\hline CIDADANIA DAS MULHERES & $\begin{array}{l}\text { BT } \\
\text { RT }\end{array}$ & $\begin{array}{l}\text { SG Lei, Governo e Políticas Públicas } \\
\text { cidadania } \\
\text { direitos reprodutivos }\end{array}$ \\
\hline DIREITOS DAS MULHERES & $\begin{array}{l}\text { BT } \\
\text { RT }\end{array}$ & $\begin{array}{l}\text { SG História e Mudança Social } \\
\quad \text { Lei, Governo e Políticas Públicas } \\
\text { direitos } \\
\text { bioética } \\
\text { direitos reprodutivos } \\
\text { feminismo } \\
\text { questão da mulher, a } \\
\text { voto feminino }\end{array}$ \\
\hline PARTICIPAÇÃO POLÍTICA & RT & $\begin{array}{l}\text { SG Lei, Governo e Políticas Públicas } \\
\text { cidadania } \\
\text { voto feminino }\end{array}$ \\
\hline
\end{tabular}

Fonte: Bruschini, Ardaillon e Unbehaum (1998, p. 44, 62, 129).

Nota-se que voto não está relacionado com o descritor "cidadania" e, tão pouco, com o descritor "cidadania das mulheres". Aparece como Termo Relacionado, portanto RT (Related Term) do descritor "direitos das mulheres". Nesse caso, também se entende que o exercício da "cidadania das mulheres" é possível pelo voto.

Em relação ao descritor "participação política" foram expostos como RT apenas dois termos - "cidadania" e "voto feminino" - que gera a conclusão da participação da mulher na política ser apenas pelos termos apontados. Com isso, o TEG não cobre no descritor "direitos das mulheres" a participação direta da mulher na política. Também é possível observar que no descritor "voto

Inf. Inf., Londrina, v. 22, n. 2, p. 166 - 207, maio/ago., 2017. http:www.uel.br/revistas/informacao/ 
feminino", não existe relacionamento estabelecido para o termo "cidadania", conforme apontado no quadro 4.

Quadro 4 - Descritores Tesauro para Estudo de Gênero e sobre Mulheres (TEG)

\begin{tabular}{|c|c|}
\hline DESCRITOR & FORMA DE APRESENTAÇÃO \\
\hline \multicolumn{2}{|l|}{ VOTO FEMININO } \\
\hline & $\begin{array}{ll} & \text { SG Lei, Governo e Políticas Públicas } \\
\text { RT } & \text { comportamento eleitoral das mulheres } \\
\text { direitos das mulheres } \\
\text { direitos políticos } \\
\text { eleições } \\
\text { eleitorado feminino } \\
\text { emancipação feminina } \\
\text { feminismo } \\
\text { participação política }\end{array}$ \\
\hline
\end{tabular}

Fonte: Bruschini, Ardaillon e Unbehaum (1998, p. 165).

É importante destacar que o Tribunal Superior Eleitoral (TSE) promoveu uma reforma na lei tornando obrigatórias $30 \%$ a proporção mínima de participação das mulheres nos partidos políticos. Esse direito é abarcado na Lei n 12.034, de 29 de setembro de 2009, no Art. 10, "§ 3o Do número de vagas resultante das regras previstas neste artigo, cada partido ou coligação preencherá o mínimo de 30\% (trinta por cento) e o máximo de $70 \%$ (setenta por cento) para candidaturas de cada sexo." (BRASIL, 2009, on-line).

Entretanto, antes dessa formulação, as normas para a realização das eleições municipais, instituída pela Lei no 9.100 de 29 de setembro de 1995, estabelecia no Art. $9^{\circ}$, " $\S 3^{\circ}$ Vinte por cento, no mínimo, das vagas de cada partido ou coligação deverão ser preenchidas por candidaturas de mulheres." (BRASIL, 1995, on-line).

Nessa dimensão, é direito da mulher se candidatar a cargos políticos e, essa conquista, colabora para o entendimento da mulher poder ocupar o lugar que desejar. Mas, os descritores no quadro 3 retirados do TEG não outorgam o direito da mulher ocupar cargos políticos.

Partindo para análise do Tesauro Jurídico do Superior Tribunal de Justiça (TJ STJ) é possível constatar limitação de representação para o descritor "mulher" e, ao total, 6 termos principais foram encontrados, conforme segue no quadro 5 .

Inf. Inf., Londrina, v. 22, n. 2, p. 166 - 207, maio/ago., 2017. http:www.uel.br/revistas/informacao/ 
Brisa Pozzi de Sousa, Vinicius de Souza Tolentino Aspectos machistas na organização do conhecimento: a representação da mulher em instrumentos documentários

Quadro 5 - Resultado de busca no Tesauro Jurídico do Superior Tribunal de Justiça $(T J \text { STJ })^{9}$

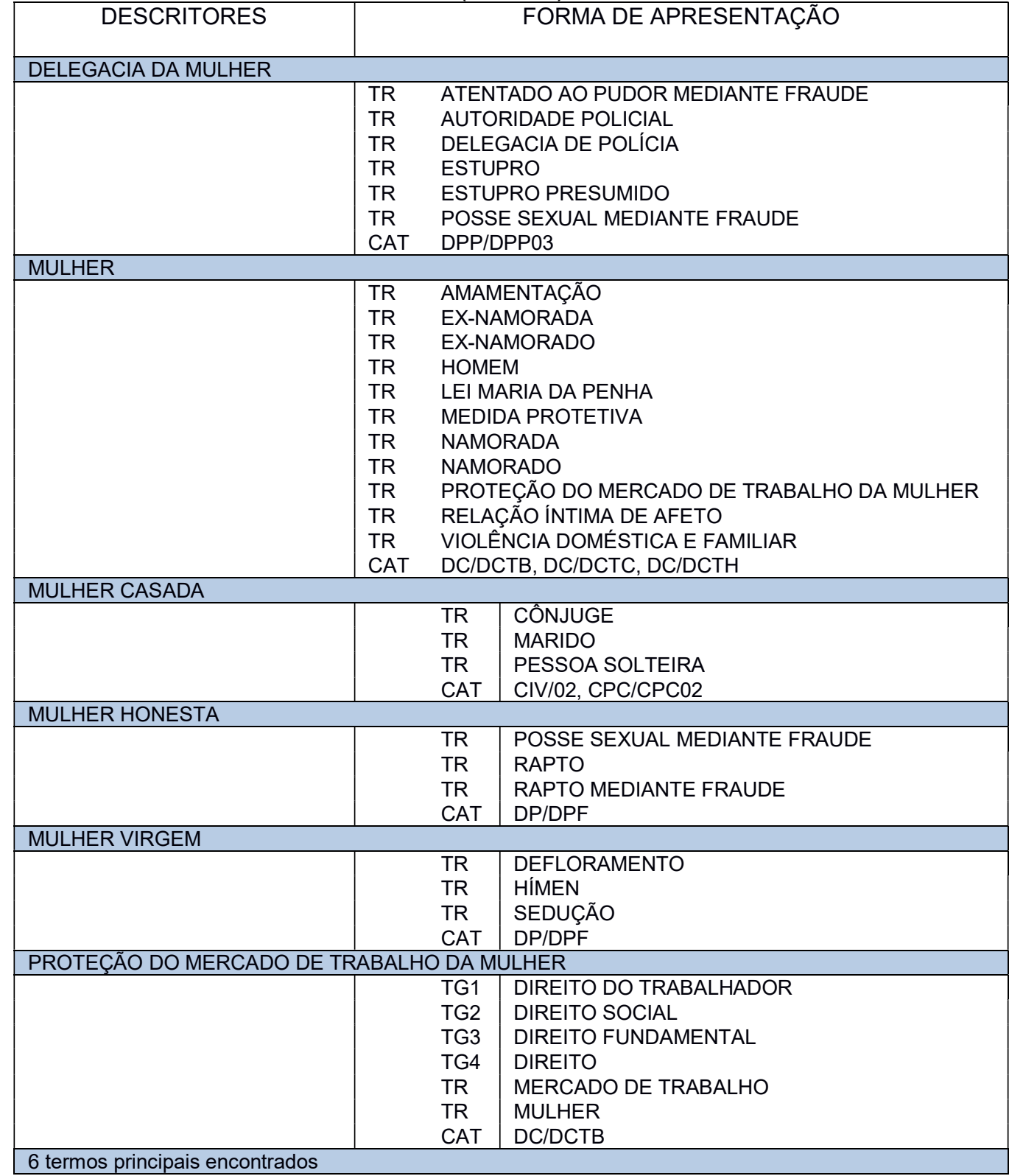

Fonte: Brasil ([200?b], on-line).

Nesse tesauro, a análise partiu para o contexto da cidadania, pois ao observar as formas de relacionamentos que envolvem o descritor mulher, encontrou-se um cenário desestimulante e pouco abrangente.

De acordo com a responsabilidade que o TJ assume no cenário brasileiro, a pressuposição que pautou a escolha do instrumento decorreu em acreditar que a mulher estaria representada por um olhar cidadão.

Inf. Inf., Londrina, v. 22, n. 2, p. 166 - 207, maio/ago., 2017. http:www.uel.br/revistas/informacao/ 
É sabido que as questões que envolvem a mulher têm se transformado ao longo dos anos e nenhuma evolução decorre completa, ou totalmente, em um curto espaço de tempo, pois precisam ser assimiladas. Por consequência, essas transformações também envolvem as formas de representação do conhecimento nos instrumentos documentários.

Sem negar tal realidade, acredita-se que a integração dos descritores deve conferir a comunidade usuária escolhas conscientes de associações, que respaldem os valores pelos quais se constroem a sociedade e a busca pela cidadania. A Constituição Federal direciona:

Art. $1^{\circ}$ República Federativa do Brasil, formada pela união indissolúvel dos Estados e Municípios e do Distrito Federal, constitui-se em Estado Democrático de Direito e tem como fundamentos: I - a soberania; II - a cidadania; III - a dignidade da pessoa humana; IV - os valores sociais do trabalho e da livre iniciativa; V - o pluralismo político. (BRASIL, 1988, on-line).

Sendo assim, o alcance do descritor mulher no TJ STJ, ilustrado no quadro 5 , deve abarcar os fundamentos democráticos pautados pela Constituição Federal. Entretanto, conforme é possível constatar (quadro 5), a maior parte dos relacionamentos estão hierarquizados na forma de Relação Associativa (TR) e a exceção decorre para o descritor "proteção do mercado de trabalho da mulher".

A análise não versará todos os 6 descritores e se baseará na escolha de um, a saber, "mulher" destacando-se o TR "homem", conforme negritado no quadro 6.

Quadro 6 - Tesauro Jurídico do Superior Tribunal de Justiça (TJ STJ)

\begin{tabular}{|l|ll|}
\hline \multicolumn{2}{|c|}{ DESCRITOR } & \multicolumn{1}{|c|}{ FORMA DE APRESENTAÇÃO } \\
\hline MULHER & TR & AMAMENTAÇÃO \\
& TR & EX-NAMORADA \\
& TR & EX-NAMORADO \\
& TR & HOMEM \\
& TR & LEI MARIA DA PENHA \\
& TR & MEDIDA PROTETIVA \\
& TR & NAMORADA \\
& TR & NAMORADO \\
& TR & PROTEÇÃO DO MERCADO DE TRABALHO DA MULHER \\
& TR & RELAÇO ÍNTIMA DE AFETO \\
& TR & VIOLÊNCIA DOMÉSTICA E FAMILIAR \\
& CAT & DC/DCTB, DC/DCTC, DC/DCTH \\
& \\
\hline
\end{tabular}

Fonte: Brasil ([200?b], on-line, grifo nosso).

Inf. Inf., Londrina, v. 22, n. 2, p. 166 - 207, maio/ago., 2017. http:www.uel.br/revistas/informacao/ 
Brisa Pozzi de Sousa, Vinicius de Souza Tolentino

Aspectos machistas na organização do conhecimento: a representação da mulher em instrumentos documentários

Ao selecionar o TR "homem" o resultado apresentado é o que segue no quadro 7.

Quadro 7 - Tesauro Jurídico do Superior Tribunal de Justiça (TJ STJ)

\begin{tabular}{|l|ll|}
\hline DESCRITOR & & \multicolumn{2}{|c|}{ FORMA DE APRESENTAÇÃO } \\
\hline \multicolumn{2}{|c|}{ DECLARAÇÃO UNIVERSAL DOS DIREITOS DO HOMEM } \\
\hline & TR & DIREITOS HUMANITÁRIOS \\
& TR & DIREITOS HUMANOS \\
& CAT & DPIDPN \\
\hline HOMEM & TR & EX-NAMORADA \\
& TR & EX-NAMORADO \\
& TR & MULHER \\
& TR & NAMORADA \\
& TR & NAMORADO \\
& TR & RELAÇÃO ÍNTIMA DE AFETO \\
& CAT & DC/DCTB \\
\hline
\end{tabular}

Fonte: Brasil ([200?b], on-line, grifo nosso.

É possível observar que o TR "direitos humanitários" e "direitos humanos" no referido tesauro estão vinculados ao TR "homem", entretanto, também deveriam estar atrelados ao descritor "mulher". A naturalização do conceito homem, na abrangência de referir-se a toda humanidade será considerada para fins de análise a partir da Declaração Universal dos Direitos Humanos de 1948 (DUDH), da Organização das Nações Unidas (ONU).

Existem outros documentos históricos tão importantes quanto o DUDH, entretanto, a singularidade deste é de ampla abrangência e, em seu preâmbulo, nota-se como objetivo atingir todos os povos e todas as nações, com o propósito de alcançar indivíduos e órgãos da sociedade para que se esforcem "[...] através do ensino e da educação, por promover o respeito a esses direitos e liberdades [...]" (ORGANIZAÇÃO DAS NAÇÕES UNIDAS, 1948, p. 2).

Um documento que busca tal universalidade deveria implicar a construção de relações mais justas e democráticas no envolvimento da temática gênero e, para essa análise, o escopo centrado na Declaração Universal dos Direitos Humanos indica a generalização de homem para representar homens e mulheres.

A referida Declaração apresenta apenas duas vezes a palavra mulheres. Primeiro, no próprio preâmbulo vincula-se a questão da igualdade, apresentando a relação entre homens e mulheres e, após, no artigo 16, quando confere o contexto de homens e mulheres de maior idade, sem qualquer

Inf. Inf., Londrina, v. 22, n. 2, p. 166 - 207, maio/ago., 2017. http:www.uel.br/revistas/informacao/ 
restrição, terem o direito de contrair o matrimônio. No restante do documento, os direitos das mulheres aparecem de forma generalizada e o fato desencadeia uma forma de apagamento, pois o quadro da generalização sinaliza que posições secundárias são exceções.

Nos dois momentos que a Declaração faz menção à mulher constata-se que o foco incide em reafirmar a posição do homem na sociedade, pois mesmo indicando no preâmbulo que a igualdade existe, em um segundo momento ela só pode ser protagonizada se houver a aderência ao matrimônio entre o homem e a mulher. Portanto, reverbera-se o papel imposto à mulher pela sociedade de ser mãe, esposa, cuidadora e dona de casa e do seu reconhecimento decorrer somente nos referidos papéis. Em consequência, essa posição reafirma a condição do homem chefe da família patriarcal.

Ademais, a partir do momento que a Declaração Universal simplifica e singulariza a complexidade histórica que envolve os direitos das mulheres em direitos universais do homem ou da humanidade, pode-se compreender que o padrão desencadeia o apagamento da mulher, bem como a reverberação da condição de subalternação em relação ao homem.

Portanto, esse cenário também é constatado no TJ STJ, pois a generalização a partir dos descritores "direitos humanitários" e "direitos humanos" são dados ao homem e não à mulher.

Nesse extrato, a lembrança da marca machista de Paulo Freire ${ }^{10}$ desencadeia-se:

Freire, ao lançar a Pedagogia do Oprimido, nos Estados Unidos, recebeu, em Genebra, inúmeras cartas de mulheres americanas. As cartas falavam do incomodo por serem excluídas da obra desse Educador, e em muito o surpreenderam. Diziam que Freire discutia a opressão, a libertação, criticava, com justa indignação, as estruturas opressoras, mas "com uma linguagem machista, portanto discriminatória", em que não havia lugar para as mulheres (FREIRE, 1992, p. 66).

Ora, quando eu falo homem, a mulher necessariamente está incluída. Em certo momento de minhas tentativas, puramente ideológicas, de justificar a mim mesmo a linguagem machista que usava, percebi a mentira ou a ocultação da verdade que havia na afirmação: "quando falo homem, a mulher está incluída". E por que os homens não se acham incluídos quando

Inf. Inf., Londrina, v. 22, n. 2, p. 166 - 207, maio/ago., 2017.

http:www.uel.br/revistas/informacao/ 
dizemos: "As mulheres estão decididas a mudar o mundo?" (FREIRE, 1992, p. 67).

Anos mais tarde, ao rever sua obra para uma reedição, o educador, assumindo a "marca machista" que sua escrita trazia, compreendeu seu "debito aquelas mulheres [...], por me terem feito ver o quanto a linguagem tem de ideologia" (FREIRE, 1992, p. 67). Contudo, o texto revisto parece ter sido publicado apenas nos Estados Unidos. As reedições no Brasil permaneceram com a mesma ideologia. De todo modo, Freire pode descobrir-se machista (BUCHMANN, 2009, p. 245-246).

Instaurada essas observações, se percebe a importância dos(as) profissionais responsáveis pela elaboração de instrumentos documentários se renderem ao aspecto machista que também norteia a OC. Assim, a ideia de "desclassificação" de García Gutiérrez (2013, 2014) elucida a necessidade de analisar o contrário ou avesso indicado pelos padrões e, assim, ir de encontro à análise aqui levantada, que apresenta pontos do masculino e do histórico patriarcal dominante na sociedade.

García Gutiérrez $(2013,2014)$ entende que a organização é uma operação cognitiva e cultural e a classificação uma operação epistemológica de categorização excludente com conceitos fechados cuja intenção é estabelecer dogmas. A classificação sempre acompanhou projetos de colonização territorial, sendo utilizada como arma de dominação. Por compreender que classificar resulta em ocultar, dividir e separar, García Gutiérrez apresenta o conceito de desclassificação como uma operação hermenêutica de concepções abertas, cujo suporte e objetivos são o pluralismo lógico, cultural, social, político e cognitivo. Desse modo, desclassificar sucede em desnudar, agregar e reunir.

Nas relações contemporâneas de pluralidade, o mundo precisa ser construído de múltiplas narrações a partir de estruturas e processos flexíveis, de uma perspectiva desclassificatória, da identidade, da memória, da cultura, do conhecimento e dos registros que são organizados.

García Gutiérrez $(2013,2014)$ chama a atenção para o fato de estruturas totalitárias que projetaram e antecederam os sistemas de OC. Analisar, indexar, resumir, classificar ou elaborar instrumentos documentários, de acordo com o autor, são executados atendendo aos mesmos níveis de sincronia e 
eficácia utilizados para produzir um automóvel e exportá-lo a indivíduos de qualquer cultura.

Essa sincronia totalitária que ameaça a OC pode ser exemplificada, segundo García Gutiérrez (2013, 2014), com a burocratização. Todos os aspectos da vida humana estão burocratizados e a cultura do impresso está enraizada, de modo que nada tem valor em uma sociedade se não estiver registrado. A organização de materiais simbólicos, como a memória e o conhecimento, é sensível ao ímpeto totalitário de modelos de controle de códigos hegemônicos, de ideologias e de identidades.

Nesse contexto, bibliotecários(as) aplicam regras procedentes do pensamento classificado convencidos(as) de que atuam com neutralidade e em benefício do sistema. García Gutiérrez não pretende eliminar a manipulação ou os preconceitos nos processos, mas pelo contrário, explicita essas presenças por meio de mecanismos críticos e autocríticos.

Ao discutir a desclassificação nos processos de representação, é possível notar como a mentalidade burocrática é um dos obstáculos mais complexos a se vencer. Superar a redução de uma ideologia sem ideologia, despersonalizada, despretensiosa, eficaz, inquestionável, igualitária, aparentemente inofensiva que segue o bem comum de uma instância neutra é um desafio (GARCÍA GUTIÉRREZ, 2013, 2014).

Diante de tais ponderações e em relação ao terceiro instrumento documentário que pautou a análise, em uma pesquisa feita no AACR2r foi possível recuperar 12 ocorrências vinculadas à mulher. A pesquisa decorreu pela busca no singular, porém, o termo no plural também foi contabilizado. De forma geral, os resultados direcionaram para regras específicas de criação de ponto de acesso para os nomes de mulheres casadas, indicações de procedimentos realizados para a transcrição do termo de tratamento utilizado no nome de mulheres com papel civil e as relações no termo mulher(es) no glossário. A seguir, seguem as transcrições das regras.

Inf. Inf., Londrina, v. 22, n. 2, p. 166 - 207, maio/ago., 2017. http:www.uel.br/revistas/informacao/ 
Termos de tratamento para a mulher casada

Devido a problemas na alfabetação de termos de tratamento para a mulher casada (p. ex., Mrs.) antes do prenome do marido, a regra 22.15B1 foi revista, de tal maneira que o termo de tratamento vem depois do prenome do marido.

[...]

22.15B Títulos de tratamento de mulheres casadas

[...]

22.1C. Inclua qualquer título de nobreza ou honorífico (veja também 22.12), bem como palavras ou frases (veja também 22.8 e 22.16) que geralmente aparecem, no todo ou em parte, associados a nomes que não incluem um sobrenome. Omita tais títulos, termos, palavras ou frases dos nomes que incluem um sobrenome (veja também 22.5 e 22.15) a não ser que o nome consista somente de um sobrenome (veja 22.15A) ou seja de uma mulher casada identificada somente pelo nome do marido e um título de tratamento (veja 22.15B1). Inclua todos os termos que indiquem posição hierárquica nos cabeçalhos de nobres quando o termo aparece geralmente associado ao nome em obras sobre a pessoa ou em fontes de referência (veja 22.6 e 22.12). Se um acréscimo eventual a um nome que inclui um sobrenome é de fato parte intrínseca deste, de acordo com fontes de referência ou com obras da pessoa ou sobre ela, inclua o título. Para o tratamento de outros termos que apareçam associados ao nome, veja 22.19B.

[...]

22.5C4. Outros sobrenomes compostos, exceto nomes de mulheres casadas cujos sobrenomes são formados pela combinação do sobrenome de solteira com o sobrenome do marido. Faça a entrada pelo primeiro elemento do sobrenome composto, a menos que a língua da pessoa seja o português. Neste caso, faça a entrada pelo último elemento.

22.5C5. Outros sobrenomes compostos. Mulheres casadas cujos sobrenomes são formados pela combinação do sobrenome de solteira com o sobrenome do marido. Faça a entrada pelo primeiro elemento do sobrenome composto (qualquer que seja a sua natureza), se a língua da pessoa for o espanhol, o francês, o húngaro, o italiano ou o checo. Em todos os demais casos, faça a entrada pelo sobrenome do marido. Para nomes ligados por hífen, veja $22.5 \mathrm{C} 3$.

[...]

22.15B. Termos de tratamento de mulheres casadas

22.15B1. Acrescente o termo de tratamento de mulheres casadas, se ela for identificada Somente pelo nome do marido. Acrescente o termo após o último elemento do nome do marido.

Ward, Humphry, Mrs.

22.15B2. Inclua o enclítico né, ligado a nomes de algumas mulheres casadas húngaras.

Magyary, Zoltánné

Beniczkyné Bajza, Lenke

22.26B. Elemento de entrada

Inf. Inf., Londrina, v. 22, n. 2, p. 166 - 207, maio/ago., 2017.

http:www.uel.br/revistas/informacao/ 


\section{$[\ldots]$}

22.26B1. Com as exceções especificadas em 22.26C-22.26F, faça a entrada de um nome indonésio constituído de mais de um elemento do nome pelo último elemento do nome. Faça remissivas do nome na ordem direta, a não ser que o primeiro elemento seja um nome europeu.

Sani, Sitti Nuraini

(Nome de mulher casada: o último elemento pode ser o nome do marido ou do pai)

$x$ Sitti Nuraini Sani

\section{$[\ldots]$}

22.28C2. Faça a entrada do nome da esposa de um homem portador de um título de nobreza pelo seu próprio nome, seguido do título do marido e do termo indicativo da posição conferida á mulher, se houver alguma posição.

[...]

\subsubsection{Mudança de nome (AACR2r: 22.2C1)}

No caso de pessoas que mudaram seu nome (p. ex., mulheres casadas, religiosos, pessoas que adquiriram título de nobreza etc.), escolha a forma do nome mais recente, a não ser que haja razão para acreditar que persistirá a forma do nome anterior como a mais conhecida.

\section{Lygia Fagundes Telles}

não Lygia Fagundes

(nome de solteira, usado pela autora antes do casamento) (CÓDIGO..., 2004, p. xxxi, 22-2, 22-4, 22-15, 22-29, 22-43, 2248, Apêndice à Edição Brasileira-6, destaque do Código).

As identificações registradas no glossário do AACR2r que fazem referência ao termo mulher são:

Esposas ver Mulheres casadas

mulheres com né no nome, 22.15B2

Mrs. ver Mulheres casadas; Termos de tratamento

Mulheres casadas húngaras com o enclítico né, 22.15B2 nomes tailandeses, $22.28 \mathrm{C} 2$ sobrenomes compostos, $22.5 \mathrm{C} 5$ $22.5 \mathrm{C} 5$, usando o nome de solteira e o sobrenome do marido,

Ap. bras. 1.2 .2

termos de tratamento no nome, 22.1C,22.15B

-né, em nomes de mulheres húngaras casadas, 22.15B2

Sobrenomes compostos, $22.5 \mathrm{C}$ mulheres casadas, $22.5 \mathrm{C} 5$

Inf. Inf., Londrina, v. 22, n. 2, p. 166 - 207, maio/ago., 2017. http:www.uel.br/revistas/informacao/ 
Termos de tratamento.

mulheres casadas, 22.1C, 22. 15B na indicação de responsabilidade, 1.1F7 (CÓDIGO..., 2004, p. índice -16, índice -21, índice -29, índice -30, índice 43, índice -44).

As ocorrências no AACR2r quando direcionadas ao termo mulher(es) fazem destaque a forma de tratamento para as que são casadas e para construção de pontos de acesso de mulheres que mudaram de nome também a partir do matrimônio e que adotaram o sobrenome do marido.

É interessante observar que no contexto brasileiro, os termos de tratamento não são identificados nos documentos e, percebe-se então, a indicação fazer parte de uma sociedade que destaca tal marcação como importante. Sendo assim, as regras reforçam o papel que a mulher deve assumir enquanto esposa e reafirma o modelo patriarcal de família.

Em nenhum momento, o Código direciona regra que trabalhe, por exemplo, com apontamentos sobre o nome social ${ }^{11}$, que é o nome de preferência escolhido por pessoas trans e travestis, para ser usado cotidianamente no lugar do nome registrado no documento oficial, pelo motivo do último não refletir a identidade de gênero. Seria de grande importância o Código também dar atenção a tal demanda.

Pesquisa realizada no catálogo da Biblioteca Nacional (BN) do Brasil com três escritoras brasileiras consagradas, a saber, Clarice Lispector, Rachel de Queiróz e Cecília Meireles demonstram que as regras indicadas no AACR2r reafirmam a condição da mulher no papel de esposa. O nome do cônjuge das referidas escritoras em nada interferiu na busca da informação, entretanto, podem estar vinculados como remissiva no ponto de acesso da autoridade.

Inf. Inf., Londrina, v. 22, n. 2, p. 166 - 207, maio/ago., 2017. http:www.uel.br/revistas/informacao/ 
Brisa Pozzi de Sousa, Vinicius de Souza Tolentino

Aspectos machistas na organização do conhecimento: a representação da mulher em instrumentos documentários

Figura 3 - Registro de autoridade Clarice Lispector

\begin{tabular}{|c|c|}
\hline Descrição & Lispector, Clarice, 1920-1977 \\
\hline Remissiva Ver (US/UF) & $\begin{array}{l}\text { Lispector, Haia, 1920-1977 } \\
\text { Quadros, Tereza, 1920-1977 } \\
\text { Palmer, Helen, 1920-1977 } \\
\text { Soares, Ilka, 1920-1977 } \\
\text { Valente, Clarice Gurgel, 1925-1977 } \\
\text { Gurgel Valente, Clarice, 1925-1977 }\end{array}$ \\
\hline Fonte positiva dos dados & $\begin{array}{l}\text { Autora de: O lustre. } 1946 \\
\text { Koogan (D.: 1925-1977) } \\
\text { http://authorities.loc.gov 27/11/2014 (D., rems.) } \\
\text { Delta (romancista e novelista brasileira; nasceu em 1925) } \\
\text { http://pt.wikipedia.org/wiki/Clarice Lispector (Clarice Lispector nasceu Haia Lispector em Chechelnyk no dia } 10 \text { de dezembro de } 1920 \\
\text { e faleceu no Rio de Janeiro, em } 9 \text { de dezembro de 1977. Foi uma escritora brasileira, nascida na Ucrânia) } \\
\text { http://www.releituras.com/clispector bio.asp (D.: 1920-1977) } \\
\text { https://pt.wikipedia.org/wiki/Clarice_Lispector (nasce em Chechelnyk, 10/12/1920 e faleceu no Rio de Janeiro, 09/12/1977; ; premiada } \\
\text { escritora e jornalista nascida na Ucrânia e naturalizada brasileira - e declarava, quanto à sua brasilidade, ser pernambucana -, autora } \\
\text { de romances, contos e ensaios sendo considerada uma das escritoras brasileiras mais importantes do século XX a a maior escritora } \\
\text { judia desde Franz Kafka. Sua obra está repleta de cenas cotidianas simples e tramas psicológicas, sendo considerada uma de suas } \\
\text { principais caracteristicas a epifania de personagens comuns em momentos do cotidiano) }\end{array}$ \\
\hline Local eletrônico e acesso & Lispector, Clarice http://www.claricelispector.com.br \\
\hline
\end{tabular}

Fonte: Catálogo de autoridade pessoa da Biblioteca Nacional (on-line).

No caso de Clarice Lispector, conforme retratado na figura 3, seu nome de casada é apresentado nas formas "Valente, Clarice Gurgel" e "Gurgel Valente, Clarice", sobrenomes que não são usuais à caracterização da referida escritora.

Quanto à escritora Rachel de Queiróz, no catálogo de autoridade da BN se quer existe vínculo com o nome do cônjuge, conforme consta na figura 4.

Figura 4 - Registro de autoridade Rachel de Queiróz

$\begin{aligned} & \text { Descrição } \text { Queiróz, Rachel de, 1910-2003 } \\ & \text { Remissiva Ver (US/UF) } \text { Queluz, Rita de, 1910-2003 } \\ & \begin{array}{l}\text { Autora de: O quinze. } 1979 \\ \text { Dic. lit, bras., } 2001 \text { (d.n., rem.) } \\ \text { http://authorities.loc.gov 8/12/2015 (D.) }\end{array} \\ & \begin{array}{l}\text { Fttps://pt.wikipedia.org/wiki/Rachel_de_Queiroz (Rachel de Queiroz nasceu em Fortaleza, no dia } 17 \text { de novembro de } 1910 \text { e faleceu no } \\ \text { Rio de Janeiro, no dia } 4 \text { de novembro de 2003, foi uma tradutora, romancista, escritora, jornalista, cronista e dramaturga) }\end{array}\end{aligned}$

Fonte: Catálogo de autoridade pessoa da Biblioteca Nacional (on-line).

A última escritora selecionada como amostra, Cecília Meireles, não possui seu nome completo registrado no catálogo de autoridade da $\mathrm{BN}$, que é Cecília Benevides de Carvalho Meireles, e o sobrenome Grillo indicado referese ao seu segundo cônjuge. A descrição segue na figura 5.

Inf. Inf., Londrina, v. 22, n. 2, p. 166 - 207, maio/ago., 2017. http:www.uel.br/revistas/informacao/ 
Figura 5 - Registro de autoridade Rachel de Queiróz

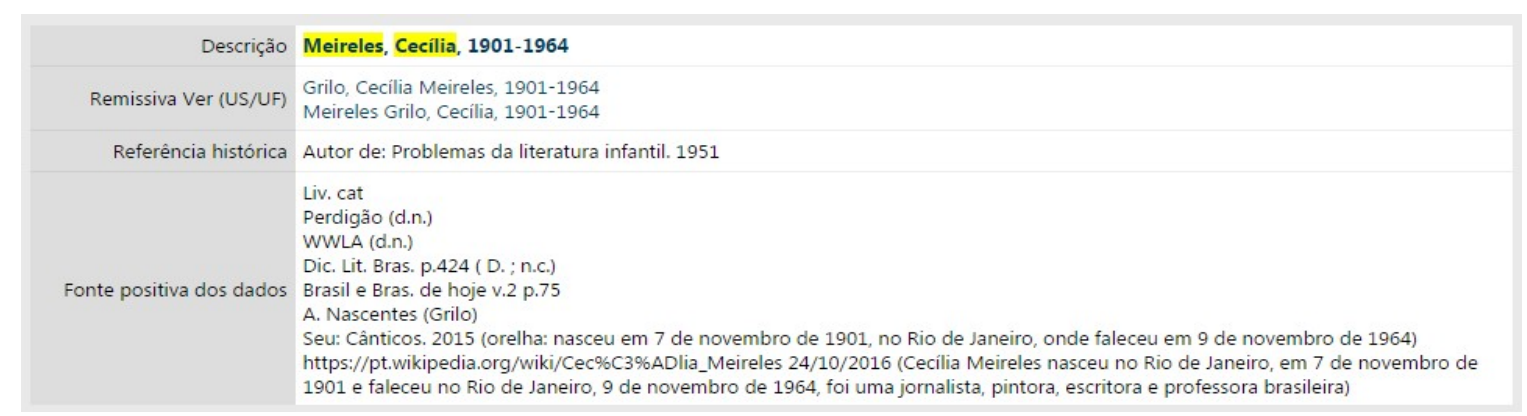

Fonte: Catálogo de autoridade pessoa da Biblioteca Nacional (on-line).

Ao trabalharem uma regra específica para a representação do termo de tratamento de mulheres casadas, percebe-se que o registro na elaboração dos documentos seja obrigatório, entretanto, para a amostra selecionada notou-se que as regras agregaram informações, mas as autoras continuaram abarcando como entrada nomes que as caracterizaram enquanto ícones da literatura brasileira e não enquanto sobrenomes oriundos do matrimônio. Com isso,

é inteiramente legítimo que uma aproximação deste tipo utilize os marcos consagrados que dão ritmo à história ocidental. Mas há outra razão que torna difícil perceber as articulações específicas em uma tal história: ela remete à inércia, nas longas durações, as representações que fundam em essência a estranheza, a inferioridade e a exclusão femininas. Estas representações inspiram camadas de discursos (ou de imagens) que constituem, nos vários séculos, modelos de compreensão com variações restritas e repetições incansáveis, e que, como se pode esperar, só se modificam quando se transforma o mundo social todo (CHARTIER,1995, p. 45, grifo nosso).

Essas demarcações encontradas no AACR2r, mesmo que pequenas, reforçam a dominação de um modelo de representação que continua a secundarizar o papel da mulher na criação, elaboração e difusão dos documentos.

\section{CONSIDERAÇÕES FINAIS}

Um dos principais elos da Organização do Conhecimento incide no relacionamento da representação temática e formal dos documentos. Nesse contexto, as escolhas dos instrumentos e aplicação das regras incidirão na

Inf. Inf., Londrina, v. 22, n. 2, p. 166 - 207, maio/ago., 2017. http:www.uel.br/revistas/informacao/ 
Brisa Pozzi de Sousa, Vinicius de Souza Tolentino

Aspectos machistas na organização do conhecimento: a representação da mulher em instrumentos documentários

elaboração dos registros documentários e, assim, a recuperação da informação torna-se possível.

A discussão empreendida nesse trabalho elucida o aspecto teóricometodológico de análise em três instrumentos documentários, perante as diversas possibilidades de explorar a Organização do Conhecimento por meio do domínio gênero, especificamente na temática mulher.

Abordou-se que a estruturação de regras, o controle e a vinculação hierárquica são caraterísticas prementes dos instrumentos documentários que se estruturam a partir de princípios significativos para emoldurar sentido na representação documentária.

Evidentemente, os instrumentos devem expressar distintas definições que o lugar social da mulher perpassa, entretanto, como apontado, os desdobramentos que compõem comportamentos, dispositivos legais e manifestações ideológicas devem ser analisados e questionados sem naturalizações.

Assim, o trabalho oferece o enfrentamento do olhar machista disposto nos instrumentos documentários, considerando o enfoque fronteiriço a ser analisado, a partir da representação da mulher.

Observou-se como os instrumentos reforçam o sentido de superioridade do homem sobre a mulher, a dominação patriarcal e a afirmação do papel feminino único enquanto esposa, dona de casa e mãe. As relações apontadas não designam formas de libertação entre homens e mulheres, não reproduzem o idêntico, não está dada. As mulheres são dominadas coletiva e individualmente pelo masculino, conforme foi possível constatar no recorte do Tesauro para Estudos de Gênero e Sobre Mulheres (TEG), no Tesauro Jurídico do Superior Tribunal de Justiça (TJ STJ) e no Anglo American Cataloguing Rules, $2^{\mathrm{a}}$ edição (AACR2r).

Quer seja na construção de descritores nos tesauros ou de regras no código de catalogação, o pensamento crítico para elaboração de instrumentos documentários não pode estar alicerçado na produção de conhecimento ilegítimo e sem envolvimento das relações entre indivíduos e sociedade.

Inf. Inf., Londrina, v. 22, n. 2, p. 166 - 207, maio/ago., 2017. http:www.uel.br/revistas/informacao/ 
Ademais, generalizar o masculino e o feminino não contribui para a obtenção de cidadania e respectivos direitos.

Se percebe a importância dos(as) profissionais responsáveis pela elaboração de instrumentos documentários encararem o aspecto machista que também norteia a Organização do Conhecimento. Assim, a ideia de "desclassificação" de García Gutiérrez $(2013,2014)$ elucida a necessidade de analisar o contrário ou avesso indicado pelos padrões e, com isso, conceber à análise que aborde pontos do masculino e do histórico patriarcal dominante na sociedade.

A pesquisa conclui que a representação da mulher nos recortes selecionados dos três diferentes instrumentos necessita de revisão, cabendo à atualização dos conceitos utilizados para que os descritores e as regras mantenham-se coerentes com a configuração social. A dicotomia construída nos instrumentos documentários não pode ordenar o masculino em relação ao feminino com critérios construídos hegemonicamente pela burocratização dos instrumentos.

As agendas de pesquisa no escopo da Organização do Conhecimento devem incluir mulher e machismo em suas discussões, possibilitando inclusive uma abordagem participativa entre sociedade e academia, para fundamentar novas perspectivas que rompam com categorias predominantes e discriminatórias.

Assim, um novo olhar sobre essa realidade demanda reformulações sobre a representação da mulher nos instrumentos documentários e, vislumbram-se profissionais e pesquisadores da Organização do Conhecimento atentos à compreensão e importância que o domínio gênero demanda.

\section{Notas de rodapé}

${ }^{1} \mathrm{Na}$ Introdução do TEG observa-se o detalhamento de como foram as tentativas de solicitação de investimento a Ford no Programa de Dotações para Pesquisa sobre Mulheres e Relações de Gênero, pois a partir desse investimento foi possível consolidar o referido tesauro (BRUSCHINI; ARDAILLON; UNBEHAUM,1998).

2 CARO CASTRO, C.; SAN SEGUNDO MANUEL, R. Lenguajes documentales y exclusión social. In: LÓPEZ-HUERTAS, M. J.; FERNÁNDEZ-MOLINA, J. C. (Ed.). La representación y la organización del conocimiento en sus distintas perspectivas: su influencia en la recuperación de la información. Granada: Universidad de Granada, 1999. p. 101-108.

Inf. Inf., Londrina, v. 22, n. 2, p. 166 - 207, maio/ago., 2017. 
${ }^{3}$ OLSON, H. A. The power to name: locating the limits or subject representation in libraries. Dordrecht: Kluwer Academic Publisher, 2002.

OLSON, H. A. Transgressive deconstructions: feminist/ postcolonial methodology for research in Knowledge Organization. In: FRÍAS, J. A.; TRAVIESO, C. (Org.). Tendencias de investigación en organización del conocimiento. Salamanca: Universidad de Salamanca, 2003. p. 731-740.

${ }^{4}$ LÓPEZ-HUERTAS, M. J.; TORRES, I.; BARITÉ, M. Terminological representation of specialized areas in conceptual structures: the case of gender studies. In: MCILWAINE, I. (Ed.). Knowledge organization and the global information society. Würzburg: ERGON Verlag, 2004. p. 35-39. (Advances in Knowledge Organization, 9).

5 LÓPEZ-HUERTAS PÉREZ, M. J.; TORRES RAMíREZ, I. de. Terminología de género. Sesgos, interrogantes, posibles respuestas. Datagramazero: Revista de Ciência da Informação, Rio de Janeiro, v. 6, n. 5, 2005.

6 Panizzi redigiu as 91 regras para serem aplicadas no catálogo do Museu Britânico, em meados do século XIX. Dentre suas principais regras destacam-se: a escolha do cabeçalho de entrada de um autor, de acordo com a forma encontrada na folha de rosto, acatando, sempre, a vontade do autor (BARBOSA, 1978).

7 Foi apresentado na Reunião Internacional de Especialistas de Catalogação um trabalho elaborado por Michael Gorman comparando os métodos descritivos de oito bibliografias nacionais. O resultado identificou elementos descritivos nas bibliografias que poderiam estabelecer uma ordem fixa com uma pontuação padrão nas descrições bibliográficas.

${ }^{8} \mathrm{O}$ referido tesauro americano foi a base para o desenho da lógica de construção do TEG e as autoras citam alguns motivos: o consideram abrangente, pelo motivo de conter 5.000 termos que cobrem 9 grandes áreas temáticas e mantem a compatibilidade com outras linguagens controladas, como por exemplo, a Lista de Cabeçalhos de Assunto da Biblioteca do Congresso norte-americano (Library of Congress Subject Headings), utilizada no Brasil, sobretudo em bibliotecas universitárias (BRUSCHINI; ARDAILLON; UNBEHAUM, 1998).

9 Ao transcrever as informações buscou-se preservar a forma do próprio tesauro e, assim, justifica-se o formato.

10 FREIRE, Paulo. Pedagogia da esperança: um reencontro com a pedagogia do oprimido. Rio de Janeiro: Paz e Terra, 1992.

11 No Brasil, o uso do nome social aparece pela primeira vez no Decreto $\mathrm{n}^{\circ} 7.037$, de 21 de dezembro de 2009, que orienta a Secretaria Especial dos Direitos Humanos da Presidência da República "desenvolver meios para garantir o uso do nome social de travestis e transexuais." (BRASIL, 2009, on-line).

\section{Agradecimentos}

Agradecemos à professora Rosali Fernandez de Souza e ao professor Gustavo Silva Saldanha a oportunidade de nos receber na disciplina Organização de Domínios de Conhecimento e por todas as contribuições para a concretização desse trabalho.

Inf. Inf., Londrina, v. 22, n. 2, p. 166 - 207, maio/ago., 2017. http:www.uel.br/revistas/informacao/ 


\section{REFERÊNCIAS}

AMERICAN NATIONAL STANDARDS INSTITUTE; NATIONAL INFORMATION STANDARDS ORGANIZATION. Z 39.19:2005: guidelines for the construction, format, and management of monolingual controlled vocabularies. Bethesda: NISO, 2005.

BARBOSA, Alice Príncipe. Novos rumos da catalogação. Rio de Janeiro: BNG: Brasilart, 1978.

BIBLIOTECA NACIONAL (BRASIL). Catálogo de autoridade pessoa. Disponível em: <http://acervo.bn.br/sophia web/index.html>. Acesso em: 30 mar. 2017.

BOBBIO, Norberto; MATTEUCCI, Nicola; PASQUINO, Gianfranco. Feminismo. . In: Dicionário de política. 13. ed. Brasília: Universidade de Brasília, 2010. v. 1. p. 485-490.

BRASIL. Constituição da República Federativa do Brasil de 1988.

Disponível em:

$<$ http://www.planalto.gov.br/ccivil 03/constituicao/constituicao.htm>. Acesso em: 30 mar. 2017.

BRASIL. Lei $\mathbf{n}^{\circ} \mathbf{9 . 1 0 0}$, de 29 de setembro de 1995 . Estabelece normas para a realização das eleições municipais de 3 de outubro de 1996, e dá outras providências. Brasília, 1996. Disponível em:

<http://www.planalto.gov.br/ccivil 03/leis/L9100.htm>. Acesso em: 30 mar. 2017.

BRASIL. Lei $\mathbf{n}^{\circ} \mathbf{1 2 . 0 3 4}$, de 29 de setembro de 2009. Altera as Leis nos 9.096 , de 19 de setembro de 1995 - Lei dos Partidos Políticos, 9.504, de 30 de setembro de 1997, que estabelece normas para as eleições, e 4.737, de 15 de julho de 1965 - Código Eleitoral. Brasília, 2009. Disponível em:

<http://www.planalto.gov.br/ccivil 03/ ato2007-2010/2009/lei//12034.htm>.

Acesso em: 30 mar. 2017.

BRASIL. Decreto № 7.037, de 21 de dezembro de 2009. Aprova o Programa Nacional de Direitos Humanos - PNDH-3 e dá outras providências. Brasília, 2009. Disponível em:

$<$ http://www.planalto.gov.br/ccivil 03/ ato2007-2010/2009/decreto/d7037.htm>. Acesso em: 3 mar. 2017.

BRASIL. Superior Tribunal de Justiça. Atribuições. [200?a]. Disponível em: $<$ http://www.stj.jus.br/sites/STJ/default/pt BR//nstitucional/Atribui\%C3\%A7\%C3 \%B5es>. Acesso em: 3 mar. 2017.

Inf. Inf., Londrina, v. 22, n. 2, p. 166 - 207, maio/ago., 2017. http:www.uel.br/revistas/informacao/ 
BRASIL. Superior Tribunal de Justiça. Secretaria de Jurisprudência do Superior Tribunal de Justiça. Consulta ao vocabulário jurídico controlado. Brasília: A Secretaria, [200?b]. Disponível em:

$<$ http://www.stj.jus.br/SCON/thesaurus/ajuda thes.jsp>. Acesso em: 27 nov. 2016.

BRUSCHINI, Cristina; ARDAILLON, Danielle; UNBEHAUM, Sandra G. Tesauro para estudos de gênero e sobre mulheres. São Paulo: Fundação Carlos Chagas; Ed. 34, 1998.

BUCHMANN, Luciano. Uma marca machista: o gênero da obra de Poty. Revista Científica/FAP, Curitiba, v. 3, p. 245-254, jan./dez. 2008.

CASTAÑEDA, Marina. O machismo invisível. São Paulo: A Girafa, 2006.

CERVANTES, Brígida Maria Nogueira; FUJITA, Mariângela Spotti Lopes. Uma perspectiva diacrônica de parâmetros e modelos de construção de tesauros. In: CERVANTES, Brígida Maria Nogueira (Org.). Horizontes da organização da informação e do conhecimento. Londrina: Eduel, 2012. p.119-138.

CHARTIER, Roger. Diferenças entre os sexos e dominação simbólica. Cadernos Pagu, Campinas, n. 4, p. 37-47, 1995.

CÓDIGO de Catalogação Anglo-Americano. 2. ed. rev. 2002. São Paulo: FEBAB; Imprensa Oficial do Estado de São Paulo, 2004.

CORREAA, Mariza. Do feminismo aos estudos de gênero no Brasil: um exemplo pessoal. Cadernos Pagu, Campinas, n. 16, p.13-30, 2001.

DEREK, Austin; PETER, Dale. Diretrizes para o estabelecimento e desenvolvimento de tesauros monolíngues. Rio de Janeiro: IBICT; SENAI, 1993.

DESCRIÇÃO Bibliográfica Internacional Normalizada (ISBD): edição consolidada. Lisboa: Biblioteca Nacional de Portugal, 2012. Tradução e revisão técnica Rosa Maria Galvão e Margarida Lopes.

FEDERAÇÃO BRASILEIRA DE ASSOCIAÇÕES DE BIBLIOTECÁRIOS. AACR2: Código de catalogação Anglo-Americano. () 2012-2016. Disponível em: <http://www.febab.org.br/aacr2-2/>. Acesso em: 08 dez. 2016.

FUJITA, Mariângela Spotti Lopes. Modelos de categorização para construção de tesauros: metodologia de ensino. In: BOCCATO, Vera Regina Casari; GRACIOSO, Luciana de Souza. Estudos de linguagem em Ciência da Informação. Campinas: Alínea, 2011. p.35-67. 
GARCÍA GUTIÉRREZ, Antonio. La organización del conocimiento em el nuevo orden transcultural: del totalitarismo a la desclassificacíon (la razón como creencia y la OC como burocracia). Brazilian Journal of Information Science: Research Trends, Marília, v. 8, n. 1/2. 2014.

GARCÍA GUTIÉRREZ, Antonio. La organizacíon del conocimiento desde la perspectiva pós-colonial: itinerários de la praconsistencia. Perspectivas em Ciência da Informação, Belo Horizonte, v. 18, n. 4, p. 93-111, out./dez. 2013.

GOMES, Hagar Espanha. Manual de elaboração de tesauros monolíngues. Brasília: Programa Nacional de Bibliotecas das Instituições de Ensino Superior, 1990.

GORMAN, Michael. 1941: an analysis and appreciation of Andrew Osborn's "the crisis in cataloging". Serials Librarian, New York, v. 6, n. 2/3, p. 127-131, winter/spring 1981/1982.

GUINCHAT, Claire; MENOU, Michel. Introdução geral às ciências e técnicas da informação e documentação. 2. ed. cor. e aum. Brasília: IBICT; FBB, 1994.

INSTITUTO BRASILEIRO DE INFORMAÇÃO EM CIÊNCIA E TECNOLOGIA. Diretrizes para elaboração de tesauros monolíngues. Brasília: IBICT, 1984.

LIBRARY OF CONGRESS. Regras de catalogação descritiva na Library of Congress: adotadas pela American Library Association. Washington: The Library of Congress, 1956. Tradução de Maria Luisa Monteiro da Cunha.

MALINCONICO, S. Michael. Technology and standards for bibliographic control. Library Quartely, Chicago, v. 47, n. 3, p. 308-325, 1977.

MARTINS, Herivelto; NASSER, David. Mamãe. 1956. Disponível em: $<$ https://www.vagalume.com.br/agnaldo-timoteo/mamae.html>. Acesso em 3 mar. 2017.

MEY, Eliane Serrão Alves. Introdução à catalogação. Brasília: Briquet de Lemos, 1995.

MILANI, Suellen Oliveira. Estudos éticos em representação do conhecimento: uma análise da questão feminina em linguagens documentais brasileiras. 2010. Dissertação (Mestrado em Ciência da Informação) Programa de Pós-Graduação em Ciência da Informação, Universidade Estadual Paulista, Marília, 2010.

Inf. Inf., Londrina, v. 22, n. 2, p. 166 - 207, maio/ago., 2017. http:www.uel.br/revistas/informacao/ 
MORAES, Miriam Gontijo de. Linguagens documentárias e a construção do pensamento crítico: reflexões sobre o tesauro para estudos de gênero e sobre a mulher. Tendências da Pesquisa Brasileira em Ciência da Informação, João Pessoa, v.7, n.1, jan./jun. 2014.

MOREIRA, Manoel Palhares. Ambiente para geração e manutenção semiautomática de tesauros. Tese (Doutorado em Ciência da Informação) Escola de Ciência da Informação, Universidade Federal de Minas Gerais, Belo Horizonte, 2005.

NOVELLINO, Maria Salet Ferreria. Instrumentos e metodologias de representação da informação. Informação \& Informação, Londrina, v. 1, n. 2, p. 37-45, jul./dez. 1996.

ORGANIZAÇÃO DAS NAÇÕES UNIDAS. Declaração Universal dos Direitos Humanos. Adotada e proclamada pela resolução 217 A (III) da Assembleia Geral das Nações Unidas em 10 de dezembro de 1948. Disponível em: $<$ http://unesdoc.unesco.org/images/0013/001394/139423por.pdf>. Acesso em: 30 mar. 2017.

ORTEGA, Cristina Dotta. Ciência da Informação: do objetivo ao objeto. In: ENCONTRO NACIONAL DE PESQUISA EM CIÊNCIA DA INFORMAÇÃO, 13., 2012, Rio de Janeiro. Anais... Rio de Janeiro, 2012.

PINSKY, Carla Bassanezi. Estudos de gênero e História Social. Estudos Feministas, Florianópolis, v. 17, n. 1, p.159-189, jan./abr. 2009.

POMBO, Olga. Da classificação dos seres à classificação dos saberes. Leituras: revista da Biblioteca Nacional de Lisboa, Lisboa, n. 2, primavera 1988. Disponível em: <http://cfcul.fc.ul.pt/textos/OP\%20\%20Da\%20Classificacao\%20dos\%20Seres\% 20a\%20Classidicacao\%20dos\%20Saberes.pdf>. Acesso em: 21 mar. 2017.

SARTI, Cynthia. Feminismo e contexto: lições do caso brasileiro. Cadernos Pagu, Campinas, n. 16, p. 31-48. 2001.

Title

Male chauvinist aspects in the Organization of Knowledge: the representation of women in documentary instruments

\section{Abstract:}

Introduction: Addressing the topic women is justified by the way in which this subject has triggered transformations that need to be understood by the Knowledge Organization (KO), involving both thematic and descriptive aspects. Research can not be detached from the social context, because the limits and definitions about the theme are not fixed and indefinable and need discussion. Objectives: It consists in the analysis of descriptors (in thesauri) and rules (in AACR2r) that provoke the indication of

Inf. Inf., Londrina, v. 22, n. 2, p. 166 - 207, maio/ago., 2017. 
male chauvinist representations, since it is essential that professionals have a critical look at the use of said instruments. Methodology: Thus, the paper analyzes womenbased representation in three different instruments: the Thesaurus for Gender and Women Studies (TEG), the Legal Thesaurus of the Superior Court of Justice (TJ STJ), and the Anglo American Cataloging Rules, 2nd edition (AACR2r). Therefore, to ascertain what is proposed, the systematization of the theoretical referential consists of the design on $\mathrm{KO}$, the woman and the instruments. Results: The analyzes demonstrate male chauvinist positions in the investigated cuts, allowing to verify the need to revise the three instruments, demanding updating of the concepts so that the descriptors and the rules remain coherent with the social (re) configuration free of prejudice. Conclusions: If the process of representation is imbued with prejudices, either because the instrument is not updated or due to lack of knowledge regarding the gender domain, the impact will have a negative effect on the public user.

Keywords: Knowledge Organization. Gender. Woman. Thesauri. Cataloging rules.

\section{Título}

Aspectos machistas en la Organización del Conocimiento: la representación de la mujer en instrumentos documentales

\section{Resumen:}

Introducción: Analizar el tema mujer se justifica por la forma en cómo ese asunto ha desencadenado transformaciones que precisan ser comprendidas por la Organización del Conocimiento (OC), involucrando tanto el aspecto temático como el descriptivo. La investigación no puede estar desvinculada del contexto social, pues los límites y las definiciones acerca del tema no son fijos e indefinibles, precisan de discusiones. Objetivo: Consiste en el análisis de descriptores (en los tesauros) y de reglas (en el AACR2r) que evidencien la indicación de representaciones machistas, pues se torna imprescindible que los profesionales tengan una mirada crítica sobre el uso de los referidos instrumentos. Metodología: Siendo así, este trabajo analiza la representación con enfoque en la mujer, en tres diferentes instrumentos: el Tesauro para Estudios de Género y sobre Mujeres (TEG), el Tesauro Jurídico del Superior Tribunal de Justicia (TJ STJ) y el Anglo American Cataloguing Rules, $2^{\mathrm{a}}$ edición (AACR2r). Por tanto, para constatar lo que se propone, la sistematización del referencial teórico consiste en el delineamiento sobre la OC, la mujer y los instrumentos. Resultados: Las análisis demuestran posturas machistas en los fragmentos investigados, permitiendo comprobar la necesidad de revisión de los tres instrumentos, demandando actualización de los conceptos para que los descriptores y las reglas se mantengan coherentes con la (re)configuración social libre de preconceptos. Conclusiones: Si el proceso de representación fuera impregnado de preconceptos, tanto por el hecho del instrumento no estar actualizado o por desconocimiento en relación al dominio género, el impacto surtirá efecto negativo en el público usuario.

Palabras-clave: Organización del Conocimiento. Género. Mujer. Tesauros. Reglas de Catalogación.

Recebido: 10.03 .2017

Aceito: 25.08.2017

Inf. Inf., Londrina, v. 22, n. 2, p. 166 - 207, maio/ago., 2017. http:www.uel.br/revistas/informacao/ 